\title{
The multifaceted anti-cancer effects of BRAF-inhibitors
}

Review

\author{
Laura Croce ${ }^{1,2}$, Francesca Coperchini ${ }^{1}$, Flavia Magri,1, Luca Chiovato ${ }^{1,3}$ and Mario \\ Rotondi ${ }^{1,3}$ \\ ${ }^{1}$ Istituti Clinici Scientifici Maugeri IRCCS, Unit of Internal Medicine and Endocrinology, Laboratory for Endocrine Disruptors, \\ University of Pavia, Pavia, Italy \\ ${ }^{2}$ PHD course in Experimental Medicine, University of Pavia, Pavia, Italy \\ ${ }^{3}$ Department of Internal Medicine and Therapeutics, University of Pavia, Pavia, Italy \\ Correspondence to: Luca Chiovato, email: luca.chiovato@icsmaugeri.it \\ Keywords: BRAF; BRAF-inhibitors; tumor microenvironment; chemokines; CXCL8
}

Received: July 22, $2019 \quad$ Accepted: October 19, $2019 \quad$ Published: November 12, 2019

Copyright: Croce et al. This is an open-access article distributed under the terms of the Creative Commons Attribution License 3.0 (CC BY 3.0), which permits unrestricted use, distribution, and reproduction in any medium, provided the original author and source are credited.

\section{ABSTRACT}

The BRAF gene is commonly involved in normal processes of cell growth and differentiation. The BRAF (V600E) mutation is found in several human cancer, causing an increase of cell proliferation due to a modification of the ERK/MAPK-signal cascade. In particular, BRAFV600E mutation is found in those melanoma or thyroid cancer refractory to the common therapy and with a more aggressive phenotype. BRAF V600E was found to influence the composition of the so-called tumour microenvironment modulating both solid (immune-cell infiltration) and soluble (chemokines) mediators, which balance characterize the ultimate behaviour of the tumour, making it more or less aggressive. In particular, the presence of BRAFV600E mutation would be associated with a change of this balance to a more aggressive phenotype of the tumour and a worse prognosis. The investigation of the possible modulation of those components of tumour microenvironment is nowadays object of several studies as a new potential target therapy in those more complicated cases. At present several clinical trials both in melanoma and thyroid cancer are using BRAF-inhibitors with encouraging results, which are derived also from numerous in vitro pre-clinical studies aimed at evaluate the possible modulation of immune-cell density and of specific protumorigenic chemokine secretion (CXCL8 and CCL2) by several BRAF-inhibitors in the context of melanoma and thyroid cancer. This review will encompass in vitro and in vivo studies which investigated the modulation of the tumour microenvironment by BRAF-inhibitors, highlighting also the most recent clinical trials with a specific focus on melanoma and thyroid cancer.

The wild type BRAF gene

The BRAF (v-raf murine sarcoma viral oncogene homolog B1) gene is located on the long arm of chromosome 7 (7q34) and encodes for an 18-exon cytoplasmic protein, a serine/threonine protein kinase (B-Raf) which is recruited to the membrane upon stimulation by growth factors. [1,2]. The wild type BRAF gene is a downstream effector within the ERK/MAPK signalling pathway, which regulates growth, proliferation, differentiation, and apoptosis in human cells. Chemical signaling through this pathway is essential for normal development before birth [2]. The BRAF gene provides instructions for the transmission of chemical signals from outside the cell to the nucleus, being the MAPKsignaling pathway typically initiated through activation of a membrane tyrosine kinase receptor [3]. This signal, through the activation of RAS, facilitates homo- or hetero-dimerization of wild-type BRAF. Activated BRAF phosphorylates MEK, which, in turn, phosphorylates ERK, resulting in multiple cellular effects such as induction of cell proliferation and survival [3]. (Figure 1A).

The mutated BRAF gene

When mutated, the $B R A F$ gene acquires oncogenic properties. Oncogenes have the potential to promote the transformation of normal to malignant cells [1-3]. 
Activating mutations of BRAF lead to the constitutive dimerization of the BRAF protein, which in turn activates the RAF-MEK-ERK signalling cascade, thus promoting cell proliferation while inhibiting apoptosis. The final result of this sequence of events is to drive cancer development and growth [3] (Figure 1B). Nowadays, more than 40 BRAF gene mutations have been identified, the majority of which result in changes of the kinase domain and the P-loop of the molecule. These mutated BRAF products actively phosphorylate MEK. Nearly $80 \%$ of these genetic alterations correspond to the hotspot T1799A trans-version that causes the V600E activating mutation, which originates from the substitution of valine with glutamic acid at amino acid (aa) 600 [1]. The remaining $20 \%$ genetic alterations of BRAF account for a wide range of missense mutations; these reside in the glycines of the G-loop (exon 11) or in the activation segment (exon 15) near the V600. An in-frame fusion of the $A K A P 9$ gene (exons 1-8) to the $B R A F$ gene (exons 9-18), which occurs through a paracentric inversion of chromosome 7 , has been preferentially recognised in radiation-induced papillary carcinomas, compared with $B R A F$ point mutations [4]. The V600E mutation confers transforming activity to the cells mainly because it mimics the phosphorylation of T599 and/or S602 in the activation segment with the consequence that BRAF remains constitutively active in a RAS independent manner [4]. Mutational studies and crystallography have shown that the BRAFV600E mutation destabilizes the inactive conformation of the enzyme and produces a constitutively active kinase with a 500-fold increased activity [5].

BRAF mutations are associated with a variety of clinical conditions. The cardiac-facies-cutaneous syndrome, a multiple congenital anomaly disorder, is due to BRAF, MEK, ERK or KRAS de novo mutations. Of note common precancerous lesions, such as melanocytic nevi, are characterized by a strikingly high frequency of BRAF-mutations, suggesting that mutational activation of the RAS/RAF/MAPK pathway is a critical step in the initiation of melanocytic neoplasia even if its presence alone is likely not sufficient for melanoma tumorigenesis $[6,7]$. Moreover, several malignancies such as melanoma, thyroid carcinoma, and although at lower frequency, colorectal cancer and non-small cell adenocarcinoma of the lung carcinoma may harbor the BRAF V600E mutation. [8-14]. Several data indicate that BRAFinhibitors block the increase in cell proliferation induced by BRAFV600E mutation (Figure 1C).

The main messages of the present section are:

- The BRAF gene is involved in proliferation, differentiation, and apoptosis of human cells.

- The mutation of the BRAF gene is associated with several human malignancies.

- BRAFV600E activating mutation promotes the RAF$M E K-E R K$ signalling cascade, thus stimulating cell proliferation while inhibiting apoptosis.
Aim of the present review is to describe currently available data regarding the role of BRAF mutations as well as the effects of BRAF-inhibitors in the tumor microenvironment. Specific focus will be put on melanoma and thyroid cancer, which share the property of being associated with a high prevalence of BRAF mutations.

\section{The tumor microenvironment in BRAF mutated neoplasia}

\section{BRAF mutation and immune cell composition of the tumor microenvironment}

The tumor microenvironment is composed of cells and soluble elements surrounding the tumor $[15,16]$. These include fibroblasts, immune cells and cells that comprise blood vessels. It also includes proteins and soluble mediators produced by the cell milieu, which ultimately support the tumor growth $[17,18]$. At present, the common belief is that disease progression is promoted by the orchestrated interaction between malignant cells and their surrounding environment $[17,18]$. This interaction is in part due to the molecular alterations of the mutated genes, which specifically drive the composition of the tumor microenvironment. In this regard, the BRAF V600E protein mutation was found to be associated with several immune-related alterations, examples of which are available both in melanoma and in differentiated thyroid cancer [1-3, 19-21].

Compared with the non-mutated ones, the microenvironment of BRAF mutated tumors is characterized by a twice as high density of FOXP3+ Regulatory $\mathrm{T}$ cells (Tregs), which, by inhibiting the anti-tumor immune response, are associated with a poor prognosis [22]. Accordingly, in the early stage of an inducible autochthonous model of mouse melanoma, an accumulation of Tregs occurs in the presence of mutated BRAF [23]. An additional mechanism of immune escape was demonstrated in human melanoma cells, in which BRAF V600E signaling impairs T cell-mediated antitumor responses by increasing the transcription of interleukin 1 alpha (IL-1a) and beta (IL-1b) in cancer-associated fibroblasts resulting in a reduction of their ability to kill melanoma cells [20].

In papillary thyroid cancer, RNA sequencing studies revealed that the presence of BRAF mutation is associated with a reduced expression of immune/inflammatory response genes as compared with wild type-BRAF tumors [24]. Other immunosuppressive molecules, including Human leukocyte antigen G (HLA-G), were also overexpressed in BRAF-mutated tumors [24]. Moreover, the Programmed death-ligand 1 (PDL-1) protein and its mRNA were found to be more abundant in surgical specimens of BRAF-mutated tumors as compared with benign tissue samples. This greater expression of PDL-1 was associated with a denser infiltrate of Treg cells and tumor-associated macrophages [25]. Recently, a genome 
expression profile analysis of infiltrating immune cells in the microenvironment the BRAF-mutated thyroid cancers showed an over-expression of a panel of genes involved in local immunosuppression processes. These included Cytotoxic T-Lymphocyte Antigen 4 (CTLA4), PDL-1 and HLA-G genes [26].

The main messages of this section are:

- The presence of the BRAF mutation deeply influences the so called "solid composition" of the tumor microenvironment of both melanoma and thyroid cancer.

- BRAF mutation promotes: i) an increase in the density of Tregs, and the secretion of IL- $1 a$ and IL-1b in cancer associated fibroblasts (consequently inhibiting the anti-tumor response); ii) a reduction of the expression of some immune/inflammatory response genes (thus inhibiting host defenses); iii) an over-expression of HLA-G and PDL-1 and other immunosuppressive genes (further reducing the immune-system response).

\section{BRAF mutation and soluble mediators in the tumor microenvironment}

Several studies investigated the chemokine milieu in tumor microenvironment and its influence on the progression and outcome of malignancy [2730]. Chemokines, an acronym derived from their proinflammatory and chemotactic activity [31], and their receptors, do influence immune cell trafficking within the tumor microenvironment, thus eventually promoting or inhibiting tumor progression $[30,32,33]$. Some chemokines, after binding to their receptors expressed on cancer cells, facilitate tumor cell growth by recruiting endothelial cells, by subverting immunologic surveillance, by altering the tumor leukocyte profile in a way that escape from antitumor immune surveillance is favored, and by promoting metastatic processes. Other chemokines play a role against neoplastic progression by increasing leukocyte migration and by inducing long-term anti-tumor immunity [34-37]. The BRAF V600E mutation, by activating the MAPK cascade, stimulates the production of a wide spectrum of chemokines by cancer cells. These oncogenedriven chemokines are responsible for the recruitment of immune cells and for their specific phenotype (i.e. mainly the myeloid lineage) [38].

Experimental studies, both on cancer cell lines and in animal models, provide strong evidence for a correlation between BRAF mutation and altered chemokine secretion in the tumor microenvironment. In human melanoma cells, BRAFV600E was shown to drive the expression of interleukin 6 (IL-6), IL-10 and vascular endothelial growth factor (VEGF), cytokines that, in vitro, promote a tolerogenic monocyte-derived dendritic cell (DC) phenotype. This process would theoretically affect the anti-tumor function of T-cell in vivo $[39,40]$. BRAFV600E was also shown to sustain the constitutive activation of the WNT/ $\beta$-catenin signaling, which in turn decreases the production of Chemokine $\mathrm{C}-\mathrm{C}$ motif ligand 4 (CCL4), an important chemokine for the recruitment of dendritic cells. Additionally, BRAFV600E was shown to induce expression of factors such as IL-10 and IL-1 $\alpha$, which can induce tolerogenic forms of dendritic cells and cancer-associated fibroblasts (CAFs), respectively [40]. More recently, the consequences of BRAF mutation on the secretion of CCL2 and chemokine (C-X-C motif) ligand 8 (CXCL8), two chemokines with proven pro-tumorigenic
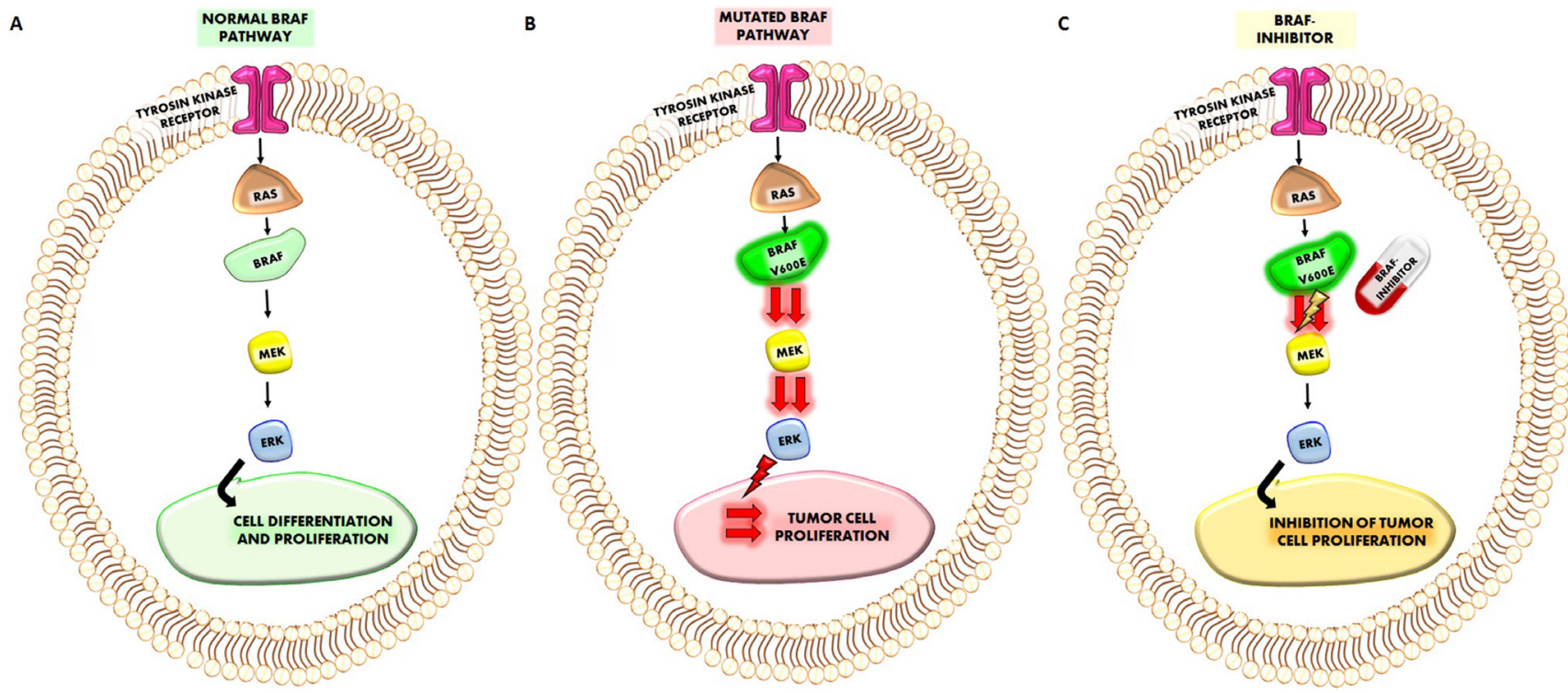

Figure 1: (A) Representation of normal BRAF pathway. The sequence of the cascade RAF-BRAF-MEK-ERK starting from the activation of Thyrosin kinase receptor, regulates normal cell differentiation and proliferation. (B) When BRAFV600E mutation occurs it will increase the activation of MEK and ERK which induce a more higher cancer cell proliferation. (C) The treatment which a given BRAF-inhibitor will reduce the increased activation of MEK (and consequently of ERK) by BRAFV600E mutation reducing also tumor cell proliferation. 
effects, were also evaluated. In a mice model of malignant glioma, the presence of a specific BRAF mutation (KIAA1549) was responsible for a higher expression of CCL2 and of its mRNA [41]. In ovarian cancer cells, the BRAF V600E mutation lead to an increased expression of CXCL8 and of vascular-endothelial-growth-factor A (VEGFA) [42].

The effect of BRAF mutation on the secretion of chemokines was also investigated in human cancer patients. In pediatric patients with Langerhans cell histiocytosis, the BRAF V600E mutation was associated with higher serum levels of the chemokine CCL7, which promotes the metastatic process by inducing epithelial to mesenchymal transition [43]. A significant correlation between elevated levels of C-X-C chemokine receptor 4 (CXCR4) mRNA and a BRAF mutation was found in tissue samples from patients with melanoma [44]. Similarly, CXCR4 levels correlate both with the degree of tumor aggressiveness and with BRAF status in papillary thyroid carcinomas [45]. Husain et al. found that, in tissue samples of anaplastic thyroid carcinoma, the levels of VEGFA, VEGFC and IL-6 increased, and were associated with the expression of BRAF V600E [46].

In view of the above data, it is likely that BRAF mutations largely regulate the expression and/or the secretion of some pro-tumorigenic chemokines in melanoma, thyroid cancer and other types of human tumors. Thus, this mutated oncogene alters the cellular and humoral composition of cancer microenvironment, eventually influencing the biological behavior of malignancy.

The main messages of this section are:

- The presence of the BRAF mutation also influences the "soluble" composition of the tumor microenvironment (chemokine secretion).

- The modulation by BRAF mutation of the secretion of several chemokines (IL-6, IL-10, VEGF, CCL4, IL-1 $\alpha$, CCL2, CXCL8, CCL7) plays a role in: i) influencing the recruitment of immune cells like DC and CAFs (counteracting to the anti-tumor function of T-cells) ii) increasing the metastatic potential of tumor cells and promoting a more aggressive course of the tumor.

\section{BRAF-inhibitor drugs}

The discovery that most malignant melanomas bear an activating mutation of BRAF [1] lead to the development of BRAF inhibitors (Table 1). These drugs were specifically designed with the aim to insert oncogenic BRAFV600E in the ATP-binding site and trap it in an inactive conformation. [47] The first drug to be tested in humans was Sorafenib, but disappointing results were obtained in melanoma patients, likely due to its greater inhibitory effect on C-RAF rather than BRAF [48]. PLX4720 (Vemurafenib) showed more encouraging results as reported in a Phase II clinical trial, where a favorable response was observed in $48 \%$ of BRAF mutated melanoma patients. The corresponding figure in dacarbazine-treated controls was 5\%. Thus, the drug was approved by FDA in 2011 and can now be prescribed in patients with metastatic or inoperable melanoma who bear a V600E mutation of the B-RAF gene [49]. Dabrafenib is another BRAF inhibitor tested in a phase III clinical trial with a $50 \%$ response rate as compared to a $6 \%$ one obtained with dacarbazine [50]. In 2013, the FDA approved Dabrafenib for the treatment of patients with advanced melanomas harboring the BRAFV600E mutation.

In spite of favorable therapeutic effects, these molecules are not free from side effects because, in wildtype BRAF cells, Vemurafenib and Dabrafenib induce a paradoxical activation of the MAP kinase pathway [51]. This event is responsible for common side effects, which include development of kerato-achantomas resulting from the over-expression of the RAS oncogene. Although at lower prevalence, the development of other tumors, including de novo melanomas, genital and oral mucosal squamo-cellular cancers and basal-cell carcinoma in patients treated with BRAF inhibitors was also reported [52]. The risk of developing a secondary cancer and mainly the lack of efficacy in BRAF-wild type tumors clearly support the contraindication of both Vemurafenib and Dabrafenib in patients with BRAF-wild type cancers. Moreover, although treatment with Vemurafenib of Dabrafenib produces some clinical benefit in nearly all patients with BRAF mutated melanomas, more than $90 \%$ of them develop resistance to these drugs within one year. Thus, the favorable effects on tumor progression-free survival are limited [49]. Based on these considerations, it seemed mandatory to search for new therapeutic strategies targeting the MEK-ERK-RAS pathway. With this aim, two new drugs, Trametinib and Cobimetinib that target MEK downstream from the BRAF in the MAP kinase pathway were developed. These drugs, mainly when combined with Vemurafenib or Dabrafenib, do improve both the overall and the progression-free survival in melanoma patients [53]. Interestingly, combination treatment with the two drugs also reduced cutaneous side effects as compared with the single-drug anti-BRAF therapy [54]. A recent study by Robert et al, reported the results of an extended survival analysis of the two combination trials with Dabrafenib and Trametinib as a first-line therapy, showing that long-term benefit in terms of overall survival can be reached in approximately one third of the patients who had unresectable or metastatic melanoma with a BRAF V600E or V600K mutation [55].

Based on the promising results obtained in melanoma, BRAF-inhibitors have been used also in other BRAF-mutated cancers, with contrasting results. Colorectal cancers that harbour the same BRAF(V600E) mutation are intrinsically resistant to BRAF inhibitors, due to feedback activation of the epidermal growth factor receptor (EGFR), although double or triple combination 
Table 1: Main BRAF and MEK inhibitors and their characteristics

\begin{tabular}{llll}
\hline Name & Formula & Target & Use \\
\hline Sorafenib & BAY43-9006 & VEGFR, PDGFR, CRAF, BRAF inhibitor & Kidney, thyroid and liver cancer \\
Vemurafenib & PLX4720, PLX4032 & BRAFV600E inhibitor & Melanoma \\
Dabrafenib & GSK2118436) & BRAFV600E inhibitor & Melanoma and Non small cell lung cancer \\
Encorafenib & LGX818 & BRAFV600E inhibitor & \\
Selumetinib & AZD6244 & MEK1 and MEK2 inhibitor & \\
Trametinib & GSK1120212 & MEK1 and MEK2 inhibitor & Melanoma \\
Cobimetinib & XL518, GDC-0973 & MEK1 and MEK2 inhibitor & Melanoma (with Vemurafenib) \\
Binimetinib & (MEK162) & MEK1 and MEK2 inhibitor & Melanoma (with Encorafenib) \\
\hline
\end{tabular}

trials gave some benefit in terms of response rate [56]. Similar results were provided by phase II trials on treatment with dabrafenib of the rare BRAF-mutated nonsmall-cell lung cancers (NSCLC) in which the BRAFinhibitor alone gave disappointing results, whereas combination with the MEK-inhibitor Tramentib produced some benefit in terms of overall response rate $[57,58]$. Similar evidences were reported in high grade gliomas treated with combined BRAF and MEK inhibitor therapy, although large series studies are still lacking [59].

Up to now, no MAPK/ERK pathway inhibitor drug is approved for the treatment of thyroid cancer [60]. However, Phase I and II clinical trials are ongoing to test the therapeutic potential of this class of drugs, alone or in combination with other pharmacological agents (Table 2). Partial results of these trials are already available. A Phase I study investigated treatment with dabrafenib and lapatinib, the latter being a dual HER2/neu and epidermal-growth factor-receptor (EGFR) inhibitor, in patients with unresectable-radioiodine refractory thyroid cancer (ClinicalTrials.gov Identifier: NCT01947023). In the first 15 enrolled patients, a $60 \%$ partial response rate and a median progression-free survival of 15 months was observed. Toxicity was reported to be acceptable [61]. Similar results were obtained in a Phase I clinical trial in which patients with several types of malignancies were treated with Dabrafenib (ClinicalTrials.gov Identifier: NCT00880321). A sub-analysis of the 14 enrolled thyroid cancer patients showed that $29 \%$ of them had a partial response, $64 \%$ experienced a $10 \%$ decrease in tumor burden and $50 \%$ had stable disease. The median progression-free survival was 11.3 months [62]. Another Phase I study evaluated the ability of Trametinib to induce re-differentiation of radioiodine-refractory BRAF V600E-mutated papillary thyroid carcinoma. Six out of 10 Trametinib-treated patients experienced a restored radioiodine uptake at whole body scan and all of them were then treated with radioiodine. Two patients had a partial response and 4 a stable disease as assessed by radiographic restaging at 3 months. Serum thyroglobulin decreased in 4 out of 6 treated patients [63]. A Phase II clinical trial assessing the effectiveness of Vemurafenib in patients with radioiodine-refractory, BRAFV600E -mutated papillary thyroid cancer reported encouraging results in terms of best overall response, duration of response, and progression-free survival. These favorable results were observed both in previously untreated patients and in those who had received therapy with multi-kinaseinhibitor drugs [64]. The overall toxicity profile was consistent with that reported in melanoma patients being treated with a BRAF inhibitor drug.

The main messages of this section are:

- BRAF-inhibitor drugs are an effective and relatively safe anti-cancer therapy in patients with melanoma harbouring the BRAF V600E mutation.

- Resistance development is still an issue for treated patients and can be only in part overcome by combining BRAF-inhibitors with other classes of anti-cancer drugs, such as MEK-inhibitors and immune checkpoint inhibitors.

- Although no BRAF-inhibitor has been approved for thyroid cancer therapy yet, this class of drugs gave interesting results in Phase I and II clinical trials including patients with thyroid cancer.

- BRAF-inhibitors are being tested also in other types of tumors, like colorectal cancer, adenocarcinoma of the lung and glioma, with promising results.

\section{BRAF-inhibitor drugs and cancer microenvironment}

A further biological effect of BRAF inhibitors is related to their anti-cancer activity in the tumor microenvironment milieu, which, by improving the antitumor activity of the patient's immune system, limits cancer progression. This topic was initially investigated by in vitro studies, which were subsequently translated in in vivo with promising results.

\section{In vitro experiences}

Several in vitro studies aimed at evaluating the effect of different BRAF-inhibitors on immuneinfiltrating cells ( $\mathrm{T}$ cells, lymphocytes, dendritic cell) 
Table 2: Clinical trials regarding BRAF-inhibitors in Thyroid cancer

\begin{tabular}{|c|c|c|c|c|c|}
\hline Phase & Drug & N. trial & Title & Published Results & Ref \\
\hline 1 & $\begin{array}{l}\text { Vemurafenib } \\
+ \text { KTN3379 }\end{array}$ & NCT02456701 & $\begin{array}{l}\text { Enhancing Radioiodine } \\
\text { Incorporation Into } \\
\text { BRAF Mutant Thyroid } \\
\text { Cancers With the } \\
\text { Combination of } \\
\text { Vemurafenib and } \\
\text { KTN3379 }\end{array}$ & l & l \\
\hline 1 & $\begin{array}{l}\text { Dabrafenib + } \\
\text { Lapatinib }\end{array}$ & NCT01947023 & $\begin{array}{l}\text { Dabrafenib and } \\
\text { Lapatinib Ditosylate in } \\
\text { Treating Patients With } \\
\text { Refractory Thyroid } \\
\text { Cancer That Cannot Be } \\
\text { Removed by Surgery }\end{array}$ & $\begin{array}{l}60 \% \text { partial response rate, median } \\
\text { progression-free survival of } 15 \\
\text { months, with acceptable toxicity. }\end{array}$ & $\begin{array}{l}\text { Rothenberg } \\
\text { et al. } 2015\end{array}$ \\
\hline 1 & Dabrafenib & NCT00880321 & $\begin{array}{l}\text { A Phase I Study to } \\
\text { Investigate the Safety, } \\
\text { Pharmacokinetics, and } \\
\text { Pharmacodynamics } \\
\text { of GSK2118436 in } \\
\text { Subjects With Solid } \\
\text { Tumors }\end{array}$ & $\begin{array}{l}29 \% \text { partial response rate, median } \\
\text { progression-free survival of } 11 \\
\text { months, with acceptable toxicity. }\end{array}$ & $\begin{array}{l}\text { Falchook et } \\
\text { al. } 2015\end{array}$ \\
\hline 2 & Vemurafenib & NCT01286753. & $\begin{array}{l}\text { A Study of Vemurafenib } \\
\text { (RO5185426) in } \\
\text { Participants With } \\
\text { Metastatic or } \\
\text { Unresectable Papillary } \\
\text { Thyroid Cancer Positive } \\
\text { for the BRAF V600 } \\
\text { Mutation }\end{array}$ & $\begin{array}{l}\text { Increase in best overall response, } \\
\text { duration of response, and } \\
\text { progression-free survival both } \\
\text { in previously untreated and in } \\
\text { multikinase-inhibitors treated patients }\end{array}$ & $\begin{array}{l}\text { Brose, et al. } \\
2016\end{array}$ \\
\hline 1 & Dabrafenib & NCT01534897 & $\begin{array}{l}\text { Re-differentiation of } \\
\text { Radioiodine-Refractory } \\
\text { BRAF V600E-mutant } \\
\text { Papillary Thyroid } \\
\text { Carcinoma With } \\
\text { GSK2118436 }\end{array}$ & $\begin{array}{l}\text { Among } 10 \text { patients with radioiodine- } \\
\text { refractory thyroid cancer } 6 \text { patients } \\
(60 \%) \text { demonstrated new radioiodine } \\
\text { uptake on whole body scan after } \\
\text { treatment with dabrafenib. All } 6 \text { were } \\
\text { treated with } 5.5 \mathrm{GBq} \text { iodine- } 131 \text {. } \\
\text { Two patients had partial responses } \\
\text { and } 4 \text { patients had stable disease on } \\
\text { standard radiographic restaging at } 3 \\
\text { months. Thyroglobulin decreased in } \\
4 \text { of } 6 \text { treated patients. One patient } \\
\text { developed squamous cell carcinoma } \\
\text { of the skin. There were no other } \\
\text { significant adverse events attributed } \\
\text { to dabrafenib. }\end{array}$ & $\begin{array}{l}\text { Rothenberg } \\
\text { et al. } 2015\end{array}$ \\
\hline 2 & Vemurafenib & NCT01709292 & $\begin{array}{l}\text { Vemurafenib } \\
\text { Neoadjuvant Trial in } \\
\text { Locally Advanced } \\
\text { Thyroid Cancer }\end{array}$ & / & / \\
\hline 2 & $\begin{array}{l}\text { Dabrafenib + } \\
\text { Trametinib }\end{array}$ & NCT01723202 & $\begin{array}{l}\text { Dabrafenib With or } \\
\text { Without Trametinib in } \\
\text { Treating Patients With } \\
\text { Recurrent Thyroid } \\
\text { Cancer }\end{array}$ & / & / \\
\hline
\end{tabular}


etinib) and

BRAFV600E

(Dabrafenib) Inhibitors

With Radioactive Iodine

(RAI) for the Treatment

of Refractory Metastatic

Differentiated Thyroid

Cancer (MERAIODE)

$\begin{array}{lll}\text { Trametinib }+ & \text { NCT01438554 } & \text { Phase 1 Study of } \\ \text { Pazopanib } & & \text { Pazopanib With } \\ & \text { GSK1120212 in } \\ & \text { Advanced Solid } \\ & \text { Tumors, Enriched } \\ & \text { With Patients With } \\ & \text { Differentiated Thyroid } \\ & \text { Cancer, Soft-tissue } \\ & \text { Sarcoma, and } \\ & \text { Cholangiocarcinoma } \\ & & \text { Trametinib in } \\ & & \text { Combination With } \\ \text { Trametinib }+\quad \text { NCT03085056 } & \text { Paclitaxel in the } \\ & & \text { Treatment of Anaplastic } \\ & & \text { Thyroid Cancer } \\ & & \text { Trametinib in } \\ & & \text { Increasing Tumoral } \\ & & \text { Iodine Incorporation in } \\ & & \text { Patients With Recurrent } \\ & & \text { or Metastatic Thyroid } \\ & & \text { Cancer }\end{array}$

Phase 1 Study of

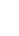

Pazopanib With

GSK1120212 in

Advanced Solid

A

ents With

Cancer, Soft-tissue

Sarcoma, and

Trametinib in

(1)

l

Treatment of Anaplastic

Cancer

of tumor microenvironment were performed. In 2010, Boni et al., found that treatment of melanoma cells with Vemurafenib (or with other MEK inhibitors) inhibited the MAPK pathway [65]. This inhibition increased the levels of the so called "Melanocyte Differentiation Agents" a class of epitopes that are associated with improved recognition by antigen-specific $\mathrm{T}$ lymphocytes [65]. Furthermore, treatment with MEK inhibitors was associated with an impaired $\mathrm{T}$ lymphocyte function, whereas T-cell function was preserved after treatment with the BRAF-inhibitor PLX4720. This represents a crucial aspect as, it would indicate that immune evasion of BRAF-mutated melanoma cells may be reversed by a specifically targeted BRAF inhibition without affecting T-cell function [65]. In a BRAF-mutated model of mouse melanoma, the BRAF-inhibitor PLX4720 selectively decreased the number of CD4+Foxp3+ Treg cells and of $\mathrm{CD} 11 \mathrm{~b}+\mathrm{Gr} 1+$ myeloid-derived suppressor cells (MDSC) in the tumor microenvironment. On the other hand, the number of CD8+ effector T cells, which are inversely correlated with tumor growth, was preserved [66]. In a BRAFV600E/PTEN-driven murine model of melanoma, PLX4720 administration increased the expression of
CD40 ligand and interferon $\gamma(\mathrm{IFN} \gamma)$ in intra-tumoral CD4 cells. This increased expression, through the enhancement of T-helper 1 (Th1) effector functions, promotes CD4 cell infiltration and activation which, in turn, leads to tumor regression. In addition, PLX4720 reduced the infiltration of Treg cells and of $\mathrm{CD} 11 \mathrm{~b}(+) / \mathrm{Gr}-1(+)$ myeloid cells, thus further inhibiting tumor growth [67]. Similar effects were also observed in mouse models of thyroid cancer. Indeed, treatment with PLX 4720 alone or in combination with Dasatinib (a BCR/ABL tyrosin-kynase inhibitor) [68], or with anti PD-L1/anti PD-1 antibodies [69] resulted in an increased peri-tumoral infiltration of $\mathrm{T}$ cells, $\mathrm{B}$ cells and macrophage/monocytes.

The effects of BRAF-inhibitors are not limited to T-cells, but also involve dendritic cells. Indeed, the secretion of tumor-necrosis-factor $\alpha$ (TNF- $\alpha$ ) and IL-12 by dendritic cells is inhibited when they are co-cultured with melanoma, cells either BRAF mutated or wild-type. The inhibition was reverted by BRAF or MEK inhibitors, but only when dendritic cells were co-cultured with melanoma cell lines carrying a BRAF V600E mutation [70]. These results fit with the concept that BRAFV600E mutated melanoma cells modulate dendritic cells through 
the MAPK pathway, because its blockade reverses the suppression of dendritic cell function [70]. In addition, Hayek et al, recently showed that BRAF-inhibitors (Vemurafenib and Dabrafenib) upregulate IL-1 $\beta$ release by mouse and human dendritic cells, thus resulting in enhanced dendritic cell-mediated anti-tumor immune responses [71]. Figure 2 summarize the major effects of BRAFV600E mutation on the solid components of the tumor microenvironment and how the administration of a BRAF-inhibitor would counteract these effects.

Moving from the action of BRAF-inhibitors on immune-infiltrating cells to their effect on cancer cells, it was demonstrated that, in BRAF-mutated melanoma cells, Vemurafenib enhances the presentation of tumor antigens [72]. This effect results from the stimulated secretion of interferons, which in turn induce the expression by neoplastic cells of major histocompatibility complex (MHC) Class I and Class II molecules. In 2010, Salerno et al, investigated the action of PLX 4270 and PLX4032 in thyroid cancer cell lines (bearing either the BRAF mutation or the RET/PTC rearrangement) and in normal thyroid cells. Both compounds inhibited the proliferation of BRAF mutated cell lines, but not of normal thyrocytes [73]. The inhibitory effect was also observed in RET/PTC rearranged cells although at a much higher concentration of the drug. Further evidence for the favorable effect of these drugs in BRAF-mutated thyroid carcinoma cells derives from the observation that treatment with PLX4032 and PLX4720 in BRAF-mutated thyroid carcinoma cells, but not in normal thyroid cells, decreases the phosphorylation of ERK1/2 and MAPK kinase (MEK)1/2. Treatment with PLX4032 and PLX4720 also induces a G1-phase block of the cell cycle and alters the expression of genes involved in the control of G1-S cellcycle transition [73]. Of note, PLX4720, by downregulating the expression of genes involved in tumor progression, reduced cell proliferation, migration and invasiveness of $8505 \mathrm{c}$, which harbor the BRAF mutation, but not in TPC-1 (wild-type for BRAF) thyroid cancer cells [74].

The anti-cancer effect of BRAF inhibitors was also studied in a orthotopic mouse model of anaplastic thyroid carcinoma, which had been obtained by injecting a thyroid cancer cell line in mice with severe combined immunodeficiency [74]. Compared with sham treated controls, BRAF-mutated tumor xenografts were smaller, less invasive and showed a lower proliferation index when mice received BRAF inhibitors [73, 75]. An even greater anti-tumor effect was observed when treatment with BRAF-inhibitors was combined with: i) anti PD-L1 or anti PD-1 antibodies [69]; ii) the BCR/ABL tyrosin-kynase inhibitor Dasatinib [68]; iii) proteasome inhibitors like Bortezomib [76]. Table 3 summarize pre-clinical studies as well as their main findings concerning this issue.

The main messages of this section are:

- BRAF-inhibitors modify the composition of tumor microenvironment in experimental settings.
- BRAF inhibitors may actually: i) increase the levels of "Melanocyte Differentiation Agents" consequently improving recognition by antigen-specific $T$ lymphocytes ii) decrease the number of Treg and $M D S C$ in the tumor microenvironment iii) increase CD40 ligand and IFNy expression by intra-tumoral CD4 cells iv) increase peri-tumoral infiltration of $T$ cells, $B$ cells and macrophage/monocytes $v)$ reverse the BRAF-induced suppression of dendritic cell function vi) inhibit proliferation of BRAF mutated cell lines, but not of normal thyrocytes.

- The anti-tumor effect of BRAF-inhibitors is even greater when they are used in combination with other classes of anticancer drugs.

\section{Translational studies}

Evidence that BRAF inhibitors do play a role in determining the specific composition of the tumor microenvironment was also provided by translational studies [77]. These studies were mostly performed on biopsy samples derived from human melanomas. Two independent biopsy series from patients with melanoma who had been treated with Vemurafenib or Dabrafenib + Trametinib showed that, compared with baseline, the expression of melanoma antigens was increased as well the number of infiltrating CD8+ T-cells [78]. A subsequent study showed that treatment with BRAF-inhibitors lead to an increased number of infiltrating CD8+ T-cells. This phenomenon was associated with a reduction in tumor size and an increase in necrotic areas in post-treatment biopsy samples [79]. Additional data [80] showed that in biopsy specimens from BRAF-inhibitors treated patients, the degree of clonality of tumor-infiltrating lymphocytes was greater. This observation implies that infiltrating T-cells are actively proliferating in response to tumor antigens [80]. A neutralization of myeloid-derived suppressor cells in the serum of patients treated with BRAF- inhibitors was also observed. [81]. Table 4 summarizes translational studies on BRAF- inhibitors of as well as their main findings.

The main messages of this section are:

- Data from preclinical models and from biopsy specimens or blood samples of patients consistently indicate that a targeted therapy with BRAF inhibitors (or with a combination of BRAF and MEK inhibitors) modifies the immune-phenotype of the tumor microenvironment. These effects are mediated by a variety of mechanisms, including increased infiltration and activity of T-cells and enhanced expression and presentation of melanocyte differentiation antigents.

\section{Resistance to BRAF inhibitors}

It should be highlighted that changes in the composition of tumor microenvironment resulting from 
treatment with BRAF-inhibitors are not persistent. The escape phenomenon contributes, at least in part, to the high rate of patients who, after an initial response to these drugs, soon develop resistance to therapy and experience clinical progression. Several mechanisms have been suggested as possible cause of resistance to BRAF/MEK inhibitors. These include EGFR and platelet-derived growth factor receptor- $\beta$ overexpressin [82], increased expression of the gene encoding the COT kinase [83], mutation of downstream MEK1 kinase [84], NRAS mutations [85], increased expression of tyrosine kinases receptor and amplification or alternative splicing of the BRAF gene $[86,87]$. Also alterations in the tumor microenvironment seem to have a role in the development of resistance to $\mathrm{BRAF} / \mathrm{MEK}$ inhibitors. Resistance to BRAF inhibitors was demonstrated in an autochthonous mouse model of melanoma and was associated, in the tumor microenvironment, with the restoration of MDSC, which, previously, had been reduced by treatment with BRAF inhibitors [66]. BRAFi-resistant melanomas are also characterized by an increased expression of PDL1 due to an increased MAPK signaling [78]. Several attempts were made for solving the problem of resistance to BRAF-inhibitors, which mainly involved adding other pharmacological compounds to BRAF-inhibitors. For example, co-treatment with MEK inhibitors partly reversed the expression of PD-L1, due to an increased MAPK signaling, which characterizes melanoma cell lines with acquired resistance to BRAF inhibitors [88]. In BRAFinhibitors-treated patients who develop drug resistance, the decreased expression of melanoma's antigens and the reduced number of infiltrating CD8 T-cell parallels the patients' clinical progression. Again, this phenomenon was largely reversed by a second-line combination of
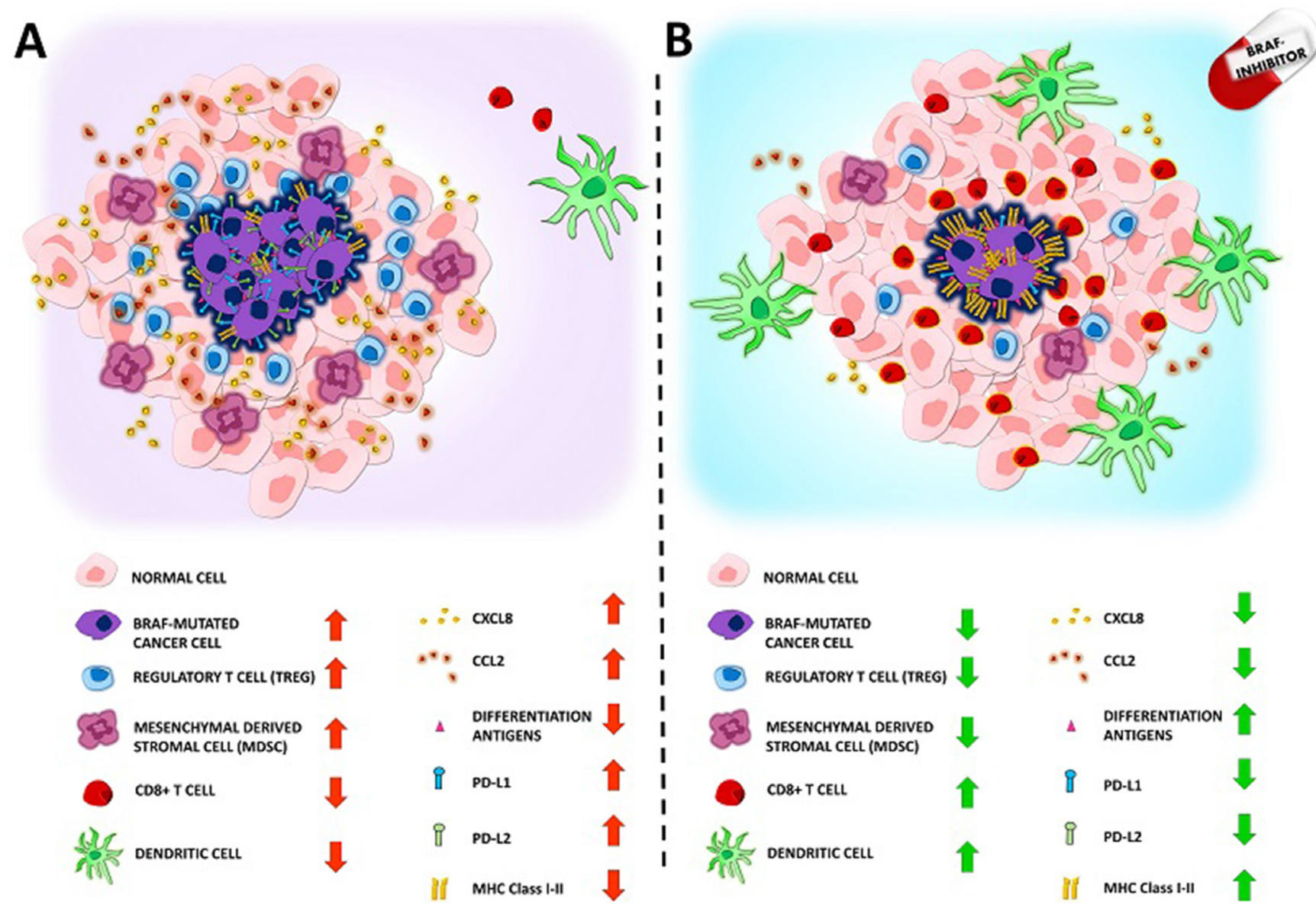

Figure 2: Panel (A) Representation of the immunosuppressive microenvironment showed in BRAF mutated cancer. The presence of BRAF V600E mutation favors cancer growth and inhibits the patients immunological response. In detail: a) regulatory $\mathrm{T}$ cells (Tregs) infiltration is increased b) Mesenchymal derived stromal cells (MDSC) infiltration is increased c) CD8+ T lymphocytes infiltration is reduced d) Dendritic cells infiltration and function is reduced e) Protumorigenic chemokines CCL2 and CXCL8 secretion is increased f) differentiation agents surface expression is reduced g) PDL1 PDL2 surface expression is increased h) MHC Class I-II surface expression is reduced. Panel (B): BRAF mutated cancer immunosuppressive microenvironment can be reverted by treatment with BRAF-inhibitors. In detail: a) regulatory $\mathrm{T}$ cells (Tregs) infiltration is reduced b) Mesenchymal derived stromal cells (MDSC) infiltration is reduced c) CD8+ $\mathrm{T}$ lymphocytes infiltration is increased d) Dendritic cells infiltration and function is increased e) Protumorigenic chemokines CCL2 and CXCL8 secretion is reduced f) Differentiation agents surface expression is increased g) PDL1 PDL2 surface expression in reduced h) MHC Class I-II surface expression is increased. 
Table 3: Pre-clinical studies regarding the effects on tumor microenvironment of BRAF-inhibitors

\begin{tabular}{|c|c|c|c|c|}
\hline Class of Drugs & $\begin{array}{l}\text { Effect on } \\
\text { microenvironment }\end{array}$ & Type of cancer & Model & ref \\
\hline BRAFi, MEKi & $\begin{array}{l}\text { Increase of Melanocyte } \\
\text { Differentiation Agents }\end{array}$ & Melanoma & Bioptic samples of treated patients & Boni et al. \\
\hline BRAFi, MEKi & $\begin{array}{l}\text { Reduction of } \\
\text { intratumoral Tregs }\end{array}$ & Melanoma & $\begin{array}{l}\text { Braf/Pten mouse model of inducible, } \\
\text { autochthonous melanoma on a pure } \\
\text { C57BL/ } 6 \text { background }\end{array}$ & $\begin{array}{l}\text { Steinberg et al. } \\
\text { Ho et al. }\end{array}$ \\
\hline BRAFi, MEKi & Reduction of MDSCs & Melanoma & $\begin{array}{l}\text { Braf/Pten mouse model of inducible, } \\
\text { autochthonous melanoma on a pure } \\
\text { C57BL/ } 6 \text { background }\end{array}$ & Steinberg et al. \\
\hline BRAFi, MEKi & $\begin{array}{l}\text { Increased dendritic } \\
\text { cells activation }\end{array}$ & Melanoma & $\begin{array}{l}\text { co-cultured monocyte-derived human } \\
\text { Dendritic cells } \\
\text { with melanoma BRAF mutated cell lines }\end{array}$ & $\begin{array}{l}\text { Ott et al. } \\
\text { Hayek et al. }\end{array}$ \\
\hline \multirow[t]{2}{*}{ BRAFi } & $\begin{array}{l}\text { Increased intratumoral } \\
\mathrm{CD} 8+\mathrm{T} \text { cells }\end{array}$ & Thyroid & $\begin{array}{l}\text { immunocompetent orthotopic mouse } \\
\text { model of V600E BRAF mutated } \\
\text { Anaplastic thyroid cancer }\end{array}$ & $\begin{array}{l}\text { Gunda et al, } \\
\text { Vanen Borre } \\
\text { et al. }\end{array}$ \\
\hline & & Melanoma & $\begin{array}{l}\text { Braf(V600E)-driven mouse melanoma } \\
\text { (SM1 and SM1WT1) and melanoma- } \\
\text { prone mice }\end{array}$ & Knight et al. \\
\hline BRAFi & $\begin{array}{l}\text { Increased intratumoral } \\
\mathrm{B} \text { cells }\end{array}$ & Thyroid & $\begin{array}{l}\text { immunocompetent orthotopic mouse } \\
\text { model of V600E BRAF mutated } \\
\text { Anaplastic throid cancer }\end{array}$ & $\begin{array}{l}\text { Gunda et al, } \\
\text { Vanen Borre } \\
\text { et al. }\end{array}$ \\
\hline BRAFi & $\begin{array}{l}\text { Increased intratumoral } \\
\text { Macrophages }\end{array}$ & Thyroid & $\begin{array}{l}\text { immunocompetent orthotopic mouse } \\
\text { model of V600E BRAF mutated } \\
\text { Anaplastic throid cancer }\end{array}$ & $\begin{array}{l}\text { Gunda et al, } \\
\text { Vanen Borre } \\
\text { et al. }\end{array}$ \\
\hline BRAFi & $\begin{array}{l}\text { Preserved normal cell } \\
\text { viability }\end{array}$ & Thyroid & Normal thyrocytes ( $\mathrm{PC} \mathrm{Cl} \mathrm{3)}$ & Salerno et al. \\
\hline BRAFi & $\begin{array}{l}\text { Increased induction of } \\
\text { MHC Class I and Class } \\
\text { II molecules by IFN }\end{array}$ & Melanoma & Melanoma cell lines & Sapkota, et al. \\
\hline BRAFi & CCL2 lowering & Melanoma & $\begin{array}{l}\text { Braf(V600E)-driven mouse melanoma (SM1 } \\
\text { and SM1WT1) and melanoma-prone mice }\end{array}$ & Knight et al. \\
\hline BRAFi & CXCL8 lowering & Thyroid & NHT, 8505C, 8305C, BCPAP cell lines & Coperchini et al. \\
\hline
\end{tabular}

Table 4: Translational studies demonstrating effects on tumor microenvironment of BRAF and MEK inhibitors

\begin{tabular}{lllll}
\hline Class of Drugs & Effect on microenvironment & Type of cancer & Model & ref \\
\hline \multirow{2}{*}{ BRAFi, MEKi } & Increase of Melanocyte & Melanoma & Bioptic samples of treated & Frederick et al. \\
& Differentiation Agents & & patients & \\
BRAFi & Reduction of MDSCs & Melanoma & Serum of treated patients & Schilling et al. \\
& Increased intratumoral CD8+ & Melanoma & $\begin{array}{l}\text { Bioptic samples of treated } \\
\text { patients }\end{array}$ & Wilmott et al. \\
BRAFi & T cells & Melanoma & Serum of treated patients & Willmott et al. \\
\hline
\end{tabular}

BRAF and MEK inhibitors [78]. Although, the combined use of BRAF and MEK inhibitors reduces the number of patients developing resistance, some patients still develop resistance even to the combined regimen, probably because of an activation of p21-activated kinases (PAKs)
[89]. These data suggest that an additional therapeutic benefit in patients with melanoma could derive from the combination of BRAF and MEK-inhibitors with other immunomodulating agents, such as immune check-points inhibitors, agonists of T-cell co-stimulatory receptors, or 
chemokine/chemokine receptor inhibitors [90]. Indeed, these pre-clinical evidences were recently confirmed by a phase Ib study evaluating the efficacy of the combination of the anti-PD-L1 antibody atezolizumab with vemurafenib alone or in combination with cobimetinib in patients with metastatic melanoma. The results showed that both combination regimens were associated with durable tumor responses, with an overall acceptable toxicity [91]. Furthermore, a randomized phase 2 trial (NCT02130466), comparing advanced melanoma patients receiving dabrafenib+trametinib in combination with the PD-1-blocking antibody pembrolizumab or placebo reported similar results [92]. Although the results of these studies were still inconclusive, ongoing Phase III trials (NCT02967692 and NCT02908672) will probably provide additional information regarding the efficacy of a triplecombination regimen.

The main messages of this section are:

- Although BRAF and MEK inhibitors provide a significant clinical benefit in melanoma patients, late resistance development remains a major clinical issue.

- Changes of the composition of the tumor microenvironment are strictly related with resistance to BRAF inhibitors.

\section{Effects of BRAF-inhibitors on chemokines in the tumor microenvironment}

The chemokine system is crucially involved in the establishment of tumor microenvironment. A close link also exists between the presence of a BRAF mutation and the secretion of chemokines by resident and infiltrating cells. Several studies, both in melanoma and in thyroid cancer, were aimed at evaluating the potential effect of BRAF-inhibitors on the secretion of chemokines. Because CCL2 has an important role in tumor progression and metastasis, this chemokine was identified as a potential therapeutic target in cancer [93]. Early studies in mice showed that PLX4720 downregulated the expression of the CCL2 gene and of its protein, both in BRAF (V600E)mutated melanoma xeno-graphs and in de novo occurring melanomas. Lowering CCL2 was followed by a reduction of tumor growth [21]. Upon development of resistance to BRAF-inhibitors, human melanoma cell lines further increase their production of CCL2. Similarly, an increase in the serum levels of CCL2 occurs in melanoma patients after extended vemurafenib treatment, and is associated with a poor clinical response [94]. In 2016 Vergani, et al., showed that CCL2 was significantly upregulated both at the transcript and at protein level in BRAF-inhibitor resistant cell lines compared with matched sensitive cells [94]. In addition, the serum levels of CCL2 were higher in patients experiencing a short-term response to BRAF-inhibitor treatment as compared with long-term responders. Taken together these results suggested that CCL2 could be viewed as a potential prognostic factor and an index for resistance to therapy in patients with melanoma [94].

A study in patients with different types of cancer, including melanoma and thyroid cancer, demonstrated that the serum concentrations of another chemokine, CXCL8, were predictive of tumor burden and extent of disease [95]. CXCL8 is the most studied chemokine in human cancer in view of its multiple pro-tumorigenic properties, which span from induction of cell growth to promotion of metastatic processes [96, 97]. Data on this chemokine regard both melanoma and thyroid cancer. Sanmamed et al, reported that patients with metastatic melanoma receiving the PD-1 inhibitor ipilimumab show a decrease or an increase in the serum levels of CXCL8 in relation to a good or poor clinical response, respectively [95]. Based on these findings, CXCL8 received increasing attention in melanoma patients as an important prognostic tool for estimating patient's tumor burden and disease-free survival $[38,98]$.

With specific regards to thyroid cancer, CXCL8 was the first chemokine shown to be secreted by normal human thyroid cells [99-101]. Since then, several studies reported that CXCL8 is also secreted by a wide variety of cancer cell lines including those derived from well-differentiated papillary, medullary, and anaplastic thyroid cancer [102-104]. Experimental evidence demonstrates that thyroid cancer cells produce larger amounts of CXCL8 as compared with normal thyroid cells. In particular, among thyroid cancer cells harboring different oncogenic mutations, those bearing the BRAF V600E mutation secrete the highest amounts of CXCL8 [105]. In the tumor microenvironment, the inhibition of CXCL8 by different compounds (metformin, phenformin, interferons, AICAR,) was proved to exert beneficial anti-tumor effects [100, 106-109]. A recent study by our group showed that the BRAF-inhibitor PLX4720 reduced CXCL8 secretion in several BRAFV600E mutated thyroid cancer cell lines $(8505 \mathrm{C}, 8305 \mathrm{C}, \mathrm{BCPAP})$, but not in RET/PTC rearranged ones (TPC1) [110]. Importantly, PLX4720 was able to reduce the migration of thyroid cancer cells, but this effect occurred only in those cells in which PLX4720 also inhibited the secretion of CXCL8 (the BRAF V600E mutated ones). In RET/PTC rearranged cells, PLX4720 did not inhibit CXCL8 secretion and had no effect on cell migration. [110]. These results highlight the concept that PLX4720, by inhibiting the secretion of CXCL8, eventually produces relevant anti-tumor effects. Figure 3 summarizes the possible consequences of BRAFinhibition on the chemokine system (Figure 3).

Taken together, experimental data in melanoma and in thyroid cancer suggest that BRAF-inhibitors not only exert direct effects on neoplastic cells, but also display an indirect anti-cancer action. The latter is mediated by a reduced secretion of CXCL8 by neoplastic cells, which in turn results in a lower aggressiveness of the tumor. This recently identified inhibition of chemokine secretion by 
PLX4720 (and potentially by other BRAF inhibitors) implies that our knowledge on the anti-cancer effects in cancer of these drugs is still incomplete. Immunotherapy is currently regarded as the future for cancer cure, and in this view targeting the chemokine/chemokine receptor system might represent a new frontier for the use of BRAF inhibitor drugs.

The main messages of this section are:

- The modulation by BRAF-inhibitors of chemokines secreted in the tumor microenvironment (in particular of CCL2 and CXCL8) ultimately affects the biological behavior of cancer cells (reducing cell growth and migration).

\section{CONCLUSIONS}

BRAF gene mutations are commonly associated with a more aggressive behaviour of melanoma or thyroid cancer. Data in the literature support the concept that, at least in part, this aggressive behavior results from changes in tumor microenvironment. In this setting, BRAF mutations play a complex role by: i) directly increasing cancer cell proliferation, ii) influencing the immune cell composition of tumor microenvironment, thus creating local immune-suppression, which favors the tumor immune-escape, iii) inducing a greater secretion of pro-tumorigenic chemokines (CXCL8, CCL2), which in turn promotes cancer cell proliferation,

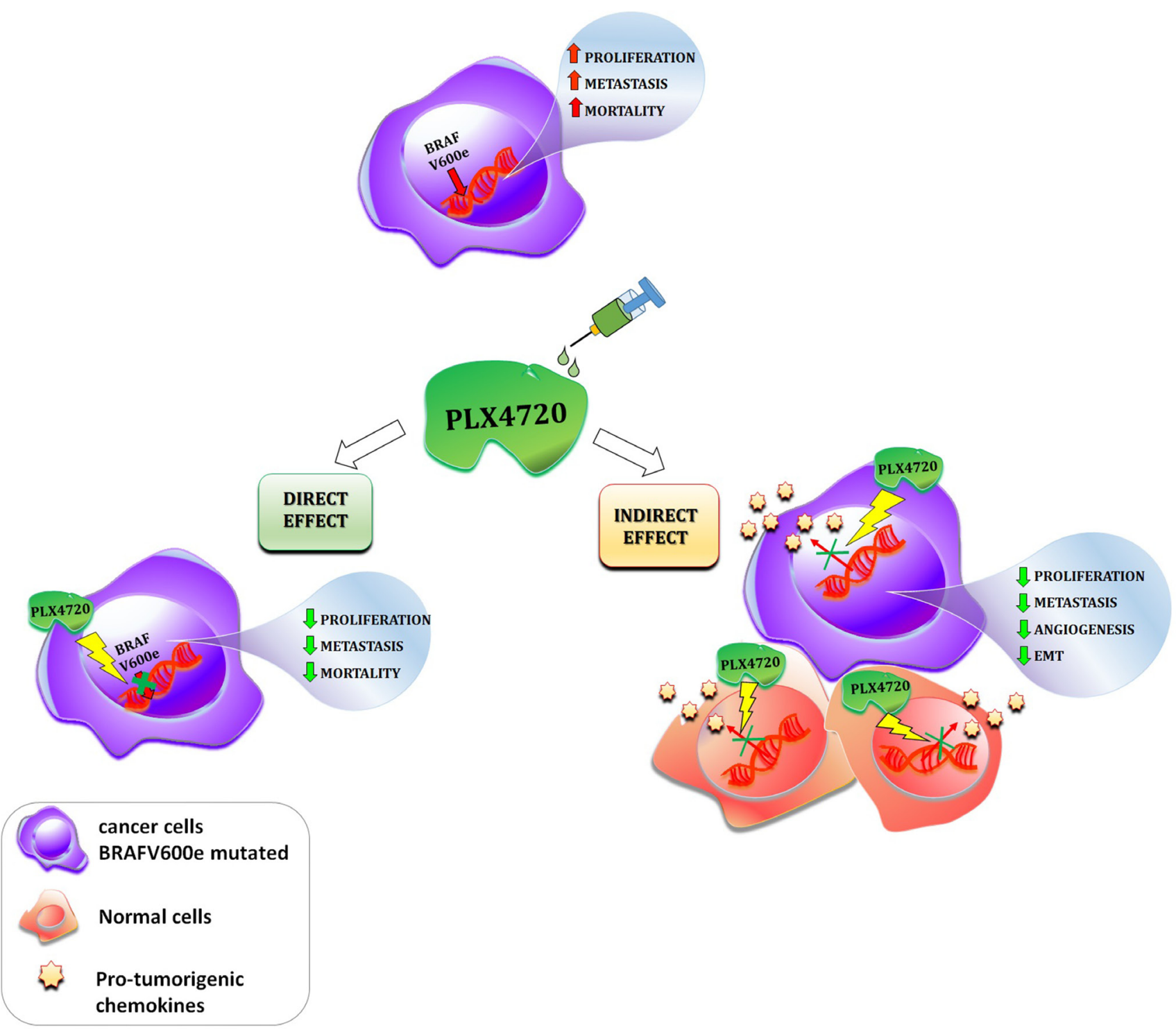

Figure 3: Schematic description of the direct and indirect effects of a given BRAF-inhibitor (PLX4720) in cancer. The presence of the BRAFV600e mutation in cancer cells leads to an increase in cell proliferation, metastasis and patients mortality. The administration of the BRAF-inhibitor PLX4720 exert both direct and indirect effect in cancer. Direct effect: PLX4720 inhibits the molecular pathway switched on by the BRAFV600e mutation, consequently cell proliferation, metastasis and patients mortality are reduced; Indirect effect: PLX4720 inhibits the secretion of pro-tumorigenic chemokines in normal surrounding and cancer cells, which in turn, leads to a reduction of cell proliferation, tumor angiogenesis, EMT and metastatic potential. 
angiogenesis and metastatization. In this context, BRAF-inhibitors could represent a useful therapeutic strategy for treatment-refractory patients with either melanoma or thyroid cancer. Indeed, experimental evidence indicates that BRAF-inhibitors directly reduce the proliferation and viability of cancer cells, and indirectly prevent the metastatic process by modulating the chemokine milieu in the tumor microenvironment. Translational studies also support the anti-cancer effect of BRAF inhibitors resulting from changes in the immunophenotype of tumor microenvironment. Clinical trials performed both in melanoma and thyroid cancer patients showed encouraging results when BRAF-inhibitors were tested alone or in combination with other drugs. The development of immunotherapy strategies focused on the tumor microenvironment of BRAF-mutated tumors will hopefully provide new tools for a personalized treatment of patients with melanoma or refractory thyroid cancer.

\section{Abbreviations}

BRAF: v-raf murine sarcoma viral oncogene homolog B1; CAF: cancer-associated fibroblasts; CCL: Chemokine (C-C motif) ligand; CTLA4: Cytotoxic T-Lymphocyte Antigen 4; CXCL: chemokine (C-X-C motif) ligand; CXCR: C-X-C chemokine receptor; DC: dendritic cell; EGFR: epidermal growth factor receptor; FDA: Food and Drug Administration; HLA: Human leukocyte antigen; IFN: interferon; IL: interleukin; MDSC: myeloid-derived suppressor cells; MHC: major histocompatibility complex; PD1: Programmed cell death protein 1; PDL1: Programmed deathligand 1; PLX4720: Plexxikon compound 7-azaindole derivative; Th1: t-helper 1; TNF: tumor necrosis factor; Treg: Regulatory T cell; VEGF: vascular endothelial growth factor.

\section{Author contributions}

Dr. Laura Croce and Dr. Francesca Coperchini collected bibliographic material, wrote the text of the manuscript and prepared figures and tables. Prof Luca Chiovato and Prof Flavia Magri provided comments on the final manuscript. Prof Mario Rotondi reviewed, edited and corrected all the manuscript.

\section{CONFLICTS OF INTEREST}

The authors have nothing to disclose.

\section{FUNDING}

No funding.

\section{REFERENCES}

1. Davies H, Bignell GR, Cox C, Stephens P, Edkins S, Clegg S, Teague J, Woffendin H, Garnett MJ, Bottomley W, Davis N, Dicks E, Ewing R, et al. Mutations of the BRAF gene in human cancer. Nature. 2002; 417:949-954. https://doi. org/10.1038/nature00766. [PubMed]

2. Dhomen N, Marais R. New insight into BRAF mutations in cancer. Curr Opin Genet Dev. 2007; 17:31-39. https://doi. org/10.1016/j.gde.2006.12.005. [PubMed]

3. Caronia LM, Phay JE, Shah MH. Role of BRAF in thyroid oncogenesis. Clin Cancer Res. 2011; 17:7511-7517. https:// doi.org/10.1158/1078-0432.CCR-11-1155. [PubMed]

4. Ciampi R, Knauf JA, Kerler R, Gandhi M, Zhu Z, Nikiforova MN, Rabes HM, Fagin JA, Nikiforov YE. Oncogenic AKAP9-BRAF fusion is a novel mechanism of MAPK pathway activation in thyroid cancer. J Clin Invest. 2005; 115:94-101. https://doi.org/10.1172/JCI23237. [PubMed]

5. Wan PT, Garnett MJ, Roe SM, Lee S, Niculescu-Duvaz D, Good VM, Jones CM, Marshall CJ, Springer CJ, Barford D, Marais R, and Cancer Genome Project. Mechanism of activation of the RAF-ERK signaling pathway by oncogenic mutations of B-RAF. Cell. 2004; 116:855-867. https://doi. org/10.1016/S0092-8674(04)00215-6. [PubMed]

6. Pollock PM, Harper UL, Hansen KS, Yudt LM, Stark M, Robbins CM, Moses TY, Hostetter G, Wagner U, Kakareka J, Salem G, Pohida T, Heenan P, et al. High frequency of BRAF mutations in nevi. Nat Genet. 2003; 33:19-20. https://doi.org/10.1038/ng1054. [PubMed]

7. Poynter JN, Elder JT, Fullen DR, Nair RP, Soengas MS, Johnson TM, Redman B, Thomas NE, Gruber SB. BRAF and NRAS mutations in melanoma and melanocytic nevi. Melanoma Res. 2006; 16:267-273. https://doi. org/10.1097/01.cmr.0000222600.73179.13. [PubMed]

8. Uhlen M, Zhang C, Lee S, Sjöstedt E, Fagerberg L, Bidkhori G, Benfeitas R, Arif M, Liu Z, Edfors F, Sanli K, von Feilitzen K, Oksvold P, et al. A pathology atlas of the human cancer transcriptome. Science. 2017; 357:eaan2507. https://doi.org/10.1126/science.aan2507. [PubMed]

9. Yan C, Huang ML, Li X, Wang T, Ling R. Relationship between BRAFV600E and clinical features in papillary thyroid carcinoma. Endocr Connect. 2019; 8:988-96. https://doi.org/10.1530/EC-19-0246. [PubMed]

10. Yoo SK, Song YS, Lee EK, Hwang J, Kim HH, Jung G, Kim YA, Kim SJ, Cho SW, Won JK, Chung EJ, Shin JY, Lee KE, et al. Integrative analysis of genomic and transcriptomic characteristics associated with progression of aggressive thyroid cancer. Nat Commun. 2019; 10:2764. https://doi.org/10.1038/s41467-019-10680-5. [PubMed]

11. Lorentzen HF. Targeted therapy for malignant melanoma. Curr Opin Pharmacol. 2019; 46:116-121. https://doi. org/10.1016/j.coph.2019.05.010. [PubMed]

12. Ducreux M, Chamseddine A, Laurent-Puig P, Smolenschi C, Hollebecque A, Dartigues P, Samallin E, Boige V, 
Malka D, Gelli M. Molecular targeted therapy of BRAFmutant colorectal cancer. Ther Adv Med Oncol. 2019; 11:1-15. $\quad$ https://doi.org/10.1177/1758835919856494. [PubMed]

13. Bernicker EH, Allen TC, Cagle PT. Update on emerging biomarkers in lung cancer. J Thorac Dis. 2019; 11:S81-S88. https://doi.org/10.21037/jtd.2019.01.46. [PubMed]

14. Yip L, Nikiforova MN, Yoo JY, McCoy KL, Stang MT, Armstrong MJ, Nicholson KJ, Ohori NP, Coyne C, Hodak SP, Ferris RL, LeBeau SO, Nikiforov YE, Carty SE. Tumor genotype determines phenotype and diseaserelated outcomes in thyroid cancer: a study of 1510 patients. Ann Surg. 2015; 262:519-25. https://doi.org/10.1097/ SLA.0000000000001420. [PubMed]

15. Mantovani A, Allavena P, Sica A, Balkwill F. Cancer-related inflammation. Nature. 2008; 454:436-444. https://doi. org/10.1038/nature07205. [PubMed]

16. Cunha LL, Marcello MA, Ward LS. The role of the inflammatory microenvironment in thyroid carcinogenesis. Endocr Relat Cancer. 2014; 21:R85-R103. https://doi. org/10.1530/ERC-13-0431. [PubMed]

17. Balkwill F, Mantovani A. Cancer and inflammation: implications for pharmacology and therapeutics. Clin Pharmacol Ther. 2010; 87:401-406. https://doi.org/10.1038/ clpt.2009.312. [PubMed]

18. Balkwill FR, Mantovani A. Cancer-related inflammation: common themes and therapeutic opportunities. Semin Cancer Biol. 2012; 22:33-40. https://doi.org/10.1016/j. semcancer.2011.12.005. [PubMed]

19. Frasca F, Nucera C, Pellegriti G, Gangemi P, Attard M, Stella M, Loda M, Vella V, Giordano C, Trimarchi F, Mazzon E, Belfiore A, Vigneri R. BRAF(V600E) mutation and the biology of papillary thyroid cancer. Endocr Relat Cancer. 2008; 15:191-205. [PubMed]

20. Khalili JS, Liu S, Rodríguez-Cruz TG, Whittington M, Wardell S, Liu C, Zhang M, Cooper ZA, Frederick DT, Li Y, Zhang M, Joseph RW, Bernatchez C, et al. Oncogenic BRAF(V600E) promotes stromal cell-mediated immunosuppression via induction of interleukin-1 in melanoma. Clin Cancer Res. 2012; 18:5329-5340. https:// doi.org/10.1158/1078-0432.CCR-12-1632. [PubMed]

21. Knight DA, Ngiow SF, Li M, Parmenter T, Mok S, Cass A, Haynes NM, Kinross K, Yagita H, Koya RC, Graeber TG, Ribas A, McArthur GA, Smyth MJ. Host immunity contributes to the anti-melanoma activity of BRAF inhibitors. J Clin Invest. 2013; 123:1371-1381. https://doi. org/10.1172/JCI66236. [PubMed]

22. Leslie C, Bowyer SE, White A, Grieu-Iacopetta F, Trevenen M, Iacopetta B, Amanuel B, Millward M. FOXP3+ $\mathrm{T}$ regulatory lymphocytes in primary melanoma are associated with BRAF mutation but not with response to BRAF inhibitor. Pathology. 2015; 47:557-563. https://doi. org/10.1097/PAT.0000000000000314. [PubMed]

23. Shabaneh TB, Molodtsov AK, Steinberg SM, Zhang P, Torres GM, Mohamed GA, Boni A, Curiel TJ, Angeles CV, Turk
MJ. Oncogenic BRAFV600E Governs Regulatory T-cell Recruitment during Melanoma Tumorigenesis. Cancer Res. 2018; 78:5038-5049. https://doi.org/10.1158/0008-5472.can18-0365. [PubMed]

24. Smallridge RC, Chindris AM, Asmann YW, Casler JD, Serie DJ, Reddi HV, Cradic KW, Rivera M, Grebe SK, Necela BM, Eberhardt NL, Carr JM, McIver B, et al. RNA sequencing identifies multiple fusion transcripts, differentially expressed genes, and reduced expression of immune function genes in BRAF (V600E) mutant vs BRAF wild-type papillary thyroid carcinoma. J Clin Endocrinol Metab. 2014; 99:E338-347. https://doi.org/10.1210/ jc.2013-2792. [PubMed]

25. Cunha LL, Marcello MA, Morari EC, Nonogaki S, Conte FF, Gerhard R, Soares FA, Vassallo J, Ward LS. Differentiated thyroid carcinomas may elude the immune system by B7H1 upregulation. Endocr Relat Cancer. 2013; 20:103-110. https://doi.org/10.1530/ERC-12-0313. [PubMed]

26. Kim K, Jeon S, Kim TM, Jung CK. Immune Gene Signature Delineates a Subclass of Papillary Thyroid Cancer with Unfavorable Clinical Outcomes. Cancers (Basel). 2018; 10:E494. https://doi.org/10.3390/cancers10120494. [PubMed]

27. Hsu DS, Kim MK, Balakumaran BS, Acharya CR, Anders CK, Clay T, Lyerly HK, Drake CG, Morse MA, Febbo PG. Immune signatures predict prognosis in localized cancer. Cancer Invest. 2010; 28:765-773. https://doi. org/10.3109/07357900903095755. [PubMed]

28. Suzuki K, Kachala SS, Kadota K, Shen R, Mo Q, Beer DG, Rusch VW, Travis WD, Adusumilli PS. Prognostic immune markers in non-small cell lung cancer. Clin Cancer Res. 2011; 17:5247-5256. https://doi.org/10.1158/1078-0432. CCR-10-2805. [PubMed]

29. Chew V, Chen J, Lee D, Loh E, Lee J, Lim KH, Weber A, Slankamenac K, Poon RT, Yang H, Ooi LL, Toh HC, Heikenwalder $\mathrm{M}$, et al. Chemokine-driven lymphocyte infiltration: an early intratumoural event determining long-term survival in resectable hepatocellular carcinoma. Gut. 2012; 61:427-438. $\quad$ https://doi.org/10.1136/gutjnl-2011-300509. [PubMed]

30. Rotondi M, Coperchini F, Latrofa F, Chiovato L. Role of Chemokines in Thyroid Cancer Microenvironment: Is CXCL8 the Main Player? Front Endocrinol (Lausanne). 2018; 9:314. https://doi.org/10.3389/fendo.2018.00314. [PubMed]

31. Rotondi M, Chiovato L, Romagnani S, Serio M, Romagnani P. Role of chemokines in endocrine autoimmune diseases. Endocr Rev. 2007; 28:492-520. https://doi.org/10.1210/ er.2006-0044. [PubMed]

32. Allavena P, Germano G, Marchesi F, Mantovani A. Chemokines in cancer related inflammation. Exp Cell Res. 2011; 317:664-673. https://doi.org/10.1016/j. yexcr.2010.11.013. [PubMed]

33. Mantovani A, Savino B, Locati M, Zammataro L, Allavena $\mathrm{P}$, Bonecchi R. The chemokine system in cancer biology and therapy. Cytokine Growth Factor Rev. 2010; 21:27-39. https://doi.org/10.1016/j.cytogfr.2009.11.007. [PubMed] 
34. Balkwill F. Chemokine biology in cancer. Semin Immunol. 2003; 15:49-55. https://doi.org/10.1016/S10445323(02)00127-6. [PubMed]

35. Kakinuma T, Hwang ST. Chemokines, chemokine receptors, and cancer metastasis. J Leukoc Biol. 2006; 79:639-651. https://doi.org/10.1189/jlb.1105633. [PubMed]

36. Sarvaiya PJ, Guo D, Ulasov I, Gabikian P, Lesniak MS. Chemokines in tumor progression and metastasis. Oncotarget. 2013; 4:2171-2185. https://doi.org/10.18632/ oncotarget.1426. [PubMed]

37. Coperchini F, Croce L, Marinò M, Chiovato L, Rotondi M. Role of chemokine receptors in thyroid cancer and immunotherapy. Endocr Relat Cancer. 2019; 26:ERC-190163.R1. https://doi.org/10.1530/ERC-19-0163. [PubMed]

38. Wilmott JS, Haydu LE, Menzies AM, Lum T, Hyman J, Thompson JF, Hersey P, Kefford RF, Scolyer RA, Long GV. Dynamics of chemokine, cytokine, and growth factor serum levels in BRAF-mutant melanoma patients during BRAF inhibitor treatment. J Immunol. 2014; 192:2505-2513. https://doi.org/10.4049/jimmunol.1302616. [PubMed]

39. Sumimoto H, Imabayashi F, Iwata T, Kawakami Y. The BRAFMAPK signaling pathway is essential for cancer-immune evasion in human melanoma cells. J Exp Med. 2006; 203:16511656. https://doi.org/10.1084/jem.20051848. [PubMed]

40. Binnewies M, Roberts EW, Kersten K, Chan V, Fearon DF, Merad M, Coussens LM, Gabrilovich DI, Ostrand-Rosenberg S, Hedrick CC, Vonderheide RH, Pittet MJ, Jain RK, et al. Understanding the tumor immune microenvironment (TIME) for effective therapy. Nat Med. 2018; 24:541-550. https://doi. org/10.1038/s41591-018-0014-x. [PubMed]

41. Chen R, Keoni C, Waker CA, Lober RM, Chen YH, Gutmann DH. KIAA1549-BRAF Expression Establishes a Permissive Tumor Microenvironment Through NFкBMediated CCL2 Production. Neoplasia. 2019; 21:52-60. https://doi.org/10.1016/j.neo.2018.11.007. [PubMed]

42. Shathasivam P, Kollara A, Spybey T, Park S, Clarke B, Ringuette MJ, Brown TJ. VEPH1 expression decreases vascularisation in ovarian cancer xenografts and inhibits VEGFA and IL8 expression through inhibition of AKT activation. Br J Cancer. 2017; 116:1065-1076. https://doi. org/10.1038/bjc.2017.51. [PubMed]

43. Morimoto A, Oh Y, Nakamura S, Shioda Y, Hayase T, Imamura T, Kudo K, Imashuku S, and Japan Langerhans cell histiocytosis Study Group. Inflammatory serum cytokines and chemokines increase associated with the disease extent in pediatric Langerhans cell histiocytosis. Cytokine. 2017; 97:7379. https://doi.org/10.1016/j.cyto.2017.05.026. [PubMed]

44. Mitchell B, Leone D, Feller JK, Bondzie P, Yang S, Park HY, Mahalingam M. Correlation of chemokine receptor CXCR4 mRNA in primary cutaneous melanoma with established histopathologic prognosticators and the BRAF status. Melanoma Res. 2014; 24:621-625. https://doi. org/10.1097/CMR.0000000000000120. [PubMed]

45. Torregrossa L, Giannini R, Borrelli N, Sensi E, Melillo RM, Leocata P, Materazzi G, Miccoli P, Santoro M,
Basolo F. CXCR4 expression correlates with the degree of tumor infiltration and BRAF status in papillary thyroid carcinomas. Mod Pathol. 2012; 25:46-55. https://doi. org/10.1038/modpathol.2011.140. [PubMed]

46. Husain A, Hu N, Sadow PM, Nucera C. Expression of angiogenic switch, cachexia and inflammation factors at the crossroad in undifferentiated thyroid carcinoma with BRAF(V600E). Cancer Lett. 2016; 380:577-585. https:// doi.org/10.1016/j.canlet.2015.07.012. [PubMed]

47. Tsai J, Lee JT, Wang W, Zhang J, Cho H, Mamo S, Bremer R, Gillette S, Kong J, Haass NK, Sproesser K, Li L, Smalley KS, et al. Discovery of a selective inhibitor of oncogenic B-Raf kinase with potent antimelanoma activity. Proc Natl Acad Sci U S A. 2008; 105:3041-3046. https:// doi.org/10.1073/pnas.0711741105. [PubMed]

48. Eisen T, Ahmad T, Flaherty KT, Gore M, Kaye S, Marais R, Gibbens I, Hackett S, James M, Schuchter LM, Nathanson KL, Xia C, Simantov R, et al. Sorafenib in advanced melanoma: a Phase II randomised discontinuation trial analysis. Br J Cancer. 2006; 95:581-586. https://doi. org/10.1038/sj.bjc.6603291. [PubMed]

49. Zhao Y, Adjei AA. The clinical development of MEK inhibitors. Nat Rev Clin Oncol. 2014; 11:385-400. https:// doi.org/10.1038/nrclinonc.2014.83. [PubMed]

50. Hauschild A, Grob JJ, Demidov LV, Jouary T, Gutzmer R, Millward M, Rutkowski P, Blank CU, Miller WH, Kaempgen E, Martín-Algarra S, Karaszewska B, Mauch C, et al. Dabrafenib in BRAF-mutated metastatic melanoma: a multicentre, open-label, phase 3 randomised controlled trial. Lancet. 2012; 380:358-365. https://doi.org/10.1016/ S0140-6736(12)60868-X. [PubMed]

51. Roskoski R. Targeting oncogenic Raf protein-serine/ threonine kinases in human cancers. Pharmacol Res. 2018; 135:239-258. https://doi.org/10.1016/j.phrs.2018.08.013. [PubMed]

52. Boussemart L, Girault I, Malka-Mahieu H, Mateus C, Routier E, Rubington M, Kamsu-Kom N, Thomas M, Tomasic G, Agoussi S, Breckler M, Laporte M, Lacroix L, et al. Secondary Tumors Arising in Patients Undergoing BRAF Inhibitor Therapy Exhibit Increased BRAF-CRAF Heterodimerization. Cancer Res. 2016; 76:1476-1484. https:// doi.org/10.1158/0008-5472.CAN-15-2900-T. [PubMed]

53. Robert C, Karaszewska B, Schachter J, Rutkowski P, Mackiewicz A, Stroiakovski D, Lichinitser M, Dummer R, Grange F, Mortier L, Chiarion-Sileni V, Drucis K, Krajsova I, et al. Improved overall survival in melanoma with combined dabrafenib and trametinib. N Engl J Med. 2015; 372:30-39. https://doi.org/10.1056/NEJMoa1412690. [PubMed]

54. Larkin J, Ascierto PA, Dréno B, Atkinson V, Liszkay G, Maio M, Mandalà M, Demidov L, Stroyakovskiy D, Thomas L, de la Cruz-Merino L, Dutriaux C, Garbe C, et al. Combined vemurafenib and cobimetinib in BRAF-mutated melanoma. N Engl J Med. 2014; 371:1867-1876. https://doi. org/10.1056/NEJMoa1408868. [PubMed] 
55. Robert C, Grob JJ, Stroyakovskiy D, Karaszewska B, Hauschild A, Levchenko E, Chiarion Sileni V, Schachter J, Garbe C, Bondarenko I, Gogas H, Mandalá M, Haanen JB, et al. Five-Year Outcomes with Dabrafenib plus Trametinib in Metastatic Melanoma. N Engl J Med. 2019; 381:626636. https://doi.org/10.1056/NEJMoa1904059. [PubMed]

56. Sanz-Garcia E, Argiles G, Elez E, Tabernero J. BRAF mutant colorectal cancer: prognosis, treatment, and new perspectives. Ann Oncol. 2017; 28:2648-2657. https://doi. org/10.1093/annonc/mdx401. [PubMed]

57. Planchard D, Smit EF, Groen HJ, Mazieres J, Besse B, Helland A, Giannone V, D'Amelio AM Jr, Zhang P, Mookerjee B, Johnson BE. Dabrafenib plus trametinib in patients with previously untreated BRAFV600E-mutant metastatic non-small-cell lung cancer: an open-label, phase 2 trial. Lancet Oncol. 2017; 18:1307-16. https://doi. org/10.1016/S1470-2045(17)30679-4. [PubMed]

58. Ai X, Guo X, Wang J, Stancu AL, Joslin PMN, Zhang D, Zhu S. Targeted therapies for advanced non-small cell lung cancer. Oncotarget. 2018; 9:37589-37607. https://doi. org/10.18632/oncotarget.26428. [PubMed]

59. Toll SA, Tran HN, Cotter J, Judkins AR, Tamrazi B, Biegel JA, Dhall G, Robison NJ, Waters K, Patel P, Cooper R, Margol AS. Sustained response of three pediatric BRAFV600E mutated high-grade gliomas to combined BRAF and MEK inhibitor therapy. Oncotarget. 2019; 10:551-557. https://doi. org/10.18632/oncotarget.26560. [PubMed]

60. Sanchez JN, Wang T, Cohen MS. BRAF and MEK Inhibitors: Use and Resistance in BRAF-Mutated Cancers. Drugs. 2018; 78:549-566. https://doi.org/10.1007/s40265018-0884-8. [PubMed]

61. Sherman EJ, Ho AL, Baxi SS, Dunn L, Korte SH, Haque S, Haque S, Ghossein RA, Chen HX, Pfister DG. Combination of dabrafenib (DAB). J Clin Oncol. 2017; 35:15S, 6085.

62. Falchook GS, Millward M, Hong D, Naing A, Piha-Paul S, Waguespack SG, Cabanillas ME, Sherman SI, Ma B, Curtis M, Goodman V, Kurzrock R. BRAF inhibitor dabrafenib in patients with metastatic BRAF-mutant thyroid cancer. Thyroid. 2015; 25:71-77. https://doi.org/10.1089/ thy.2014.0123. [PubMed]

63. Rothenberg SM, McFadden DG, Palmer EL, Daniels GH, Wirth LJ. Redifferentiation of iodine-refractory BRAF V600E-mutant metastatic papillary thyroid cancer with dabrafenib. Clin Cancer Res. 2015; 21:1028-1035. https:// doi.org/10.1158/1078-0432.CCR-14-2915. [PubMed]

64. Brose MS, Cabanillas ME, Cohen EE, Wirth LJ, Riehl T, Yue H, Sherman SI, Sherman EJ. Vemurafenib in patients with BRAF(V600E)-positive metastatic or unresectable papillary thyroid cancer refractory to radioactive iodine: a non-randomised, multicentre, open-label, phase 2 trial. Lancet Oncol. 2016; 17:1272-1282. https://doi.org/10.1016/ S1470-2045(16)30166-8. [PubMed]

65. Boni A, Cogdill AP, Dang P, Udayakumar D, Njauw CN, Sloss CM, Ferrone CR, Flaherty KT, Lawrence DP, Fisher DE, Tsao H, Wargo JA. Selective BRAFV600E inhibition enhances T-cell recognition of melanoma without affecting lymphocyte function. Cancer Res. 2010; 70:5213-5219. https://doi.org/10.1158/0008-5472.CAN-10-0118. [PubMed]

66. Steinberg SM, Shabaneh TB, Zhang P, Martyanov V, Li Z, Malik BT, Wood TA, Boni A, Molodtsov A, Angeles CV, Curiel TJ, Whitfield ML, Turk MJ. Myeloid Cells That Impair Immunotherapy Are Restored in Melanomas with Acquired Resistance to BRAF Inhibitors. Cancer Res. 2017; 77:1599-1610. https://doi.org/10.1158/0008-5472.CAN-161755. [PubMed]

67. Ho PC, Meeth KM, Tsui YC, Srivastava B, Bosenberg MW, Kaech SM. Immune-based antitumor effects of BRAF inhibitors rely on signaling by CD40L and IFN $\gamma$. Cancer Res. 2014; 74:3205-3217. https://doi.org/10.1158/00085472.CAN-13-3461. [PubMed]

68. Vanden Borre P, Gunda V, McFadden DG, Sadow PM, Varmeh S, Bernasconi M, Parangi S. Combined BRAF(V600E)- and SRC-inhibition induces apoptosis, evokes an immune response and reduces tumor growth in an immunocompetent orthotopic mouse model of anaplastic thyroid cancer. Oncotarget. 2014; 5:3996-4010. https://doi. org/10.18632/oncotarget.2130. [PubMed]

69. Gunda V, Gigliotti B, Ndishabandi D, Ashry T, McCarthy M, Zhou Z, Amin S, Freeman GJ, Alessandrini A, Parangi S. Combinations of BRAF inhibitor and anti-PD-1/PDL1 antibody improve survival and tumour immunity in an immunocompetent model of orthotopic murine anaplastic thyroid cancer. Br J Cancer. 2018; 119:1223-1232. https:// doi.org/10.1038/s41416-018-0296-2. [PubMed]

70. Ott PA, Henry T, Baranda SJ, Frleta D, Manches O, Bogunovic D, Bhardwaj N. Inhibition of both BRAF and MEK in BRAF(V600E) mutant melanoma restores compromised dendritic cell (DC) function while having differential direct effects on DC properties. Cancer Immunol Immunother. 2013; 62:811-822. https://doi.org/10.1007/ s00262-012-1389-z. [PubMed]

71. Hajek E, Krebs F, Bent R, Haas K, Bast A, Steinmetz I, Tuettenberg A, Grabbe S, Bros M. BRAF inhibitors stimulate inflammasome activation and interleukin 1 beta production in dendritic cells. Oncotarget. 2018; 9:28294-28308. https://doi. org/10.18632/oncotarget.25511. [PubMed]

72. Sapkota B, Hill CE, Pollack BP. Vemurafenib enhances MHC induction in BRAFV600E homozygous melanoma cells. OncoImmunology. 2013; 2:e22890. https://doi.org/10.4161/ onci.22890. [PubMed]

73. Salerno P, De Falco V, Tamburrino A, Nappi TC, Vecchio G, Schweppe RE, Bollag G, Santoro M, Salvatore G. Cytostatic activity of adenosine triphosphate-competitive kinase inhibitors in BRAF mutant thyroid carcinoma cells. J Clin Endocrinol Metab. 2010; 95:450-455. https://doi. org/10.1210/jc.2009-0373. [PubMed]

74. Nucera C, Porrello A, Antonello ZA, Mekel M, Nehs MA, Giordano TJ, Gerald D, Benjamin LE, Priolo C, Puxeddu E, Finn S, Jarzab B, Hodin RA, et al. B-Raf(V600E) and thrombospondin-1 promote thyroid cancer progression. 
Proc Natl Acad Sci USA. 2010; 107:10649-10654. https:// doi.org/10.1073/pnas.1004934107. [PubMed]

75. Nucera C, Nehs MA, Nagarkatti SS, Sadow PM, Mekel M, Fischer AH, Lin PS, Bollag GE, Lawler J, Hodin RA, Parangi S. Targeting BRAFV600E with PLX4720 displays potent antimigratory and anti-invasive activity in preclinical models of human thyroid cancer. Oncologist. 2011; 16:296309. https://doi.org/10.1634/theoncologist.2010-0317. [PubMed]

76. Tsumagari K, Abd Elmageed ZY, Sholl AB, Green EA, Sobti S, Khan AR, Kandil A, Murad F, Friedlander P, Boulares AH, Kandil E. Bortezomib sensitizes thyroid cancer to BRAF inhibitor in vitro and in vivo. Endocr Relat Cancer. 2018; 25:99-109. https://doi.org/10.1530/ERC-170182. [PubMed]

77. Bergdorf KN, Ferguson DC, Mehrad M, Ely K, Stricker T, Weiss VL. Papillary thyroid carcinoma behavior: clues in the tumor microenvironment. Endocr Relat Cancer. 2019; 26:ERC-19-0074.R1. https://doi.org/10.1530/ERC-19-0074. [PubMed]

78. Frederick DT, Piris A, Cogdill AP, Cooper ZA, Lezcano C, Ferrone CR, Mitra D, Boni A, Newton LP, Liu C, Peng $\mathrm{W}$, Sullivan RJ, Lawrence DP, et al. BRAF inhibition is associated with enhanced melanoma antigen expression and a more favorable tumor microenvironment in patients with metastatic melanoma. Clin Cancer Res. 2013; 19:12251231. https://doi.org/10.1158/1078-0432.CCR-12-1630. [PubMed]

79. Wilmott JS, Long GV, Howle JR, Haydu LE, Sharma RN, Thompson JF, Kefford RF, Hersey P, Scolyer RA. Selective BRAF inhibitors induce marked T-cell infiltration into human metastatic melanoma. Clin Cancer Res. 2012; 18:1386-1394. https://doi.org/10.1158/1078-0432.CCR-112479. [PubMed]

80. Cooper ZA, Frederick DT, Juneja VR, Sullivan RJ, Lawrence DP, Piris A, Sharpe AH, Fisher DE, Flaherty KT, Wargo JA. BRAF inhibition is associated with increased clonality in tumor-infiltrating lymphocytes. Oncoimmunology. 2013; 2:e26615. https://doi.org/10.4161/ onci.26615. [PubMed]

81. Schilling B, Paschen A. Immunological consequences of selective BRAF inhibitors in malignant melanoma: Neutralization of myeloid-derived suppressor cells. Oncoimmunology. 2013; 2:e25218. https://doi.org/10.4161/ onci.25218. [PubMed]

82. Sun C, Wang L, Huang S, Heynen GJ, Prahallad A, Robert C, Haanen J, Blank C, Wesseling J, Willems SM, Zecchin D, Hobor S, Bajpe PK, et al. Reversible and adaptive resistance to BRAF(V600E) inhibition in melanoma. Nature. 2014; 508:118-122. https://doi.org/10.1038/nature13121. [PubMed]

83. Johannessen CM, Boehm JS, Kim SY, Thomas SR, Wardwell L, Johnson LA, Emery CM, Stransky N, Cogdill AP, Barretina J, Caponigro G, Hieronymus H, Murray RR, et al. COT drives resistance to RAF inhibition through MAP kinase pathway reactivation. Nature. 2010; 468:968-972. https://doi.org/10.1038/nature09627. [PubMed]

84. Wagle N, Emery C, Berger MF, Davis MJ, Sawyer A, Pochanard P, Kehoe SM, Johannessen CM, Macconaill LE, Hahn WC, Meyerson M, Garraway LA. Dissecting therapeutic resistance to RAF inhibition in melanoma by tumor genomic profiling. J Clin Oncol. 2011; 29:30853096. https://doi.org/10.1200/JCO.2010.33.2312. [PubMed]

85. Nazarian R, Shi H, Wang Q, Kong X, Koya RC, Lee H, Chen Z, Lee MK, Attar N, Sazegar H, Chodon T, Nelson SF, McArthur G, et al. Melanomas acquire resistance to B-RAF(V600E) inhibition by RTK or N-RAS upregulation. Nature. 2010; 468:973-977. https://doi.org/10.1038/ nature09626. [PubMed]

86. Poulikakos PI, Persaud Y, Janakiraman M, Kong X, Ng C, Moriceau G, Shi H, Atefi M, Titz B, Gabay MT, Salton M, Dahlman KB, Tadi M, et al. RAF inhibitor resistance is mediated by dimerization of aberrantly spliced BRAF(V600E). Nature. 2011; 480:387-390. https://doi. org/10.1038/nature10662. [PubMed]

87. Shi H, Moriceau G, Kong X, Lee MK, Lee H, Koya RC, Ng C, Chodon T, Scolyer RA, Dahlman KB, Sosman JA, Kefford $\mathrm{RF}$, Long GV, et al. Melanoma whole-exome sequencing identifies (V600E)B-RAF amplification-mediated acquired B-RAF inhibitor resistance. Nat Commun. 2012; 3:724. https://doi.org/10.1038/ncomms1727. [PubMed]

88. Jiang X, Zhou J, Giobbie-Hurder A, Wargo J, Hodi FS. The activation of MAPK in melanoma cells resistant to BRAF inhibition promotes PD-L1 expression that is reversible by MEK and PI3K inhibition. Clin Cancer Res. 2013; 19:598-609. https://doi.org/10.1158/1078-0432.CCR-12-2731. [PubMed]

89. Lu H, Liu S, Zhang G, Bin Wu, Zhu Y, Frederick DT, Hu Y, Zhong W, Randell S, Sadek N, Zhang W, Chen G, Cheng $\mathrm{C}$, et al. PAK signalling drives acquired drug resistance to MAPK inhibitors in BRAF-mutant melanomas. Nature. 2017; 550:133-136. https://doi.org/10.1038/nature24040. [PubMed]

90. Homet Moreno B, Mok S, Comin-Anduix B, Hu-Lieskovan $\mathrm{S}$, Ribas A. Combined treatment with dabrafenib and trametinib with immune-stimulating antibodies for BRAF mutant melanoma. Oncoimmunology. 2015; 5:e1052212. https://doi.org/10.1080/2162402X.2015.1052212. [PubMed]

91. Sullivan RJ, Hamid O, Gonzalez R, Infante JR, Patel MR, Hodi FS, Lewis KD, Tawbi HA, Hernandez G, Wongchenko MJ, Chang Y, Roberts L, Ballinger M, et al. Atezolizumab plus cobimetinib and vemurafenib in BRAF-mutated melanoma patients. Nat Med. 2019; 25:929-935. https:// doi.org/10.1038/s41591-019-0474-7. [PubMed]

92. Ascierto PA, Ferrucci PF, Fisher R, Del Vecchio M, Atkinson V, Schmidt H, Schachter J, Queirolo P, Long GV, Di Giacomo AM, Svane IM, Lotem M, Bar-Sela G, et al. Dabrafenib, trametinib and pembrolizumab or placebo in BRAF-mutant melanoma. Nat Med. 2019; 25:941-946. https://doi.org/10.1038/s41591-019-0448-9. [PubMed]

93. Li M, Knight DA, A Snyder L, Smyth MJ, Stewart TJ. A role for CCL2 in both tumor progression and 
immunosurveillance. Oncoimmunology. 2013; 2:e25474. https://doi.org/10.4161/onci.25474. [PubMed]

94. Vergani E, Di Guardo L, Dugo M, Rigoletto S, Tragni G, Ruggeri R, Perrone F, Tamborini E, Gloghini A, Arienti F, Vergani B, Deho P, De Cecco L, et al. Overcoming melanoma resistance to vemurafenib by targeting CCL2-induced miR34a, miR-100 and miR-125b. Oncotarget. 2016; 7:44284441. https://doi.org/10.18632/oncotarget.6599. [ubMed]

95. Sanmamed MF, Carranza-Rua O, Alfaro C, Oñate C, MartínAlgarra S, Perez G, Landazuri SF, Gonzalez A, Gross S, Rodriguez I, Muñoz-Calleja C, Rodríguez-Ruiz M, Sangro B, et al. Serum interleukin- 8 reflects tumor burden and treatment response across malignancies of multiple tissue origins. Clin Cancer Res. 2014; 20:5697-5707. https://doi. org/10.1158/1078-0432.CCR-13-3203. [ubMed]

96. Xie K. Interleukin- 8 and human cancer biology. Cytokine Growth Factor Rev. 2001; 12:375-391. https://doi. org/10.1016/S1359-6101(01)00016-8. [PubMed]

97. Rotondi M, Coperchini F, Chiovato L. CXCL8 in thyroid disease: from basic notions to potential applications in clinical practice. Cytokine Growth Factor Rev. 2013; 24:539-546. https://doi.org/10.1016/j.cytogfr.2013.08.001. [PubMed]

98. Ugurel S, Rappl G, Tilgen W, Reinhold U. Increased serum concentration of angiogenic factors in malignant melanoma patients correlates with tumor progression and survival. J Clin Oncol. 2001; 19:577-583. https://doi.org/10.1200/ JCO.2001.19.2.577. [PubMed]

99. Rotondi M, Coperchini F, Pignatti P, Sideri R, Groppelli G, Leporati P, La Manna L, Magri F, Mariotti S, Chiovato L. Interferon- $\gamma$ and tumor necrosis factor- $\alpha$ sustain secretion of specific CXC chemokines in human thyrocytes: a first step toward a differentiation between autoimmune and tumor-related inflammation? J Clin Endocrinol Metab. 2013; 98:308-313. https://doi.org/10.1210/jc.2012-2555. [PubMed]

100. Rotondi M, Coperchini F, Sideri R, Groppelli G, de Martinis L, Villani L, Pignatti P, Magri F, Chiovato L. Type I and type II interferons inhibit both basal and tumor necrosis factor$\alpha$-induced CXCL8 secretion in primary cultures of human thyrocytes. J Interferon Cytokine Res. 2013; 33:508-513. https://doi.org/10.1089/jir.2012.0080. [PubMed]

101. Weetman AP, Bennett GL, Wong WL. Thyroid follicular cells produce interleukin-8. J Clin Endocrinol Metab. 1992; 75:328-330. https://doi.org/10.1210/jcem.75.1.1619027. [PubMed]

102. Basolo F, Giannini R, Toniolo A, Casalone R, Nikiforova M, Pacini F, Elisei R, Miccoli P, Berti P, Faviana P, Fiore L, Monaco C, Pierantoni GM, et al. Establishment of a nontumorigenic papillary thyroid cell line (FB-2) carrying the
RET/PTC1 rearrangement. Int J Cancer. 2002; 97:608-614. https://doi.org/10.1002/ijc.10116. [PubMed]

103. Yoshida M, Matsuzaki H, Sakata K, Takeya M, Kato K, Mizushima S, Kawakita M, Takatsuki K. Neutrophil chemotactic factors produced by a cell line from thyroid carcinoma. Cancer Res. 1992; 52:464-469. [PubMed]

104. Alfaro C, Sanmamed MF, Rodríguez-Ruiz ME, Teijeira Á, Oñate C, González Á, Ponz M, Schalper KA, PérezGracia JL, Melero I. Interleukin-8 in cancer pathogenesis, treatment and follow-up. Cancer Treat Rev. 2017; 60:24-31. https://doi.org/10.1016/j.ctrv.2017.08.004. [PubMed]

105. Coperchini F, Pignatti P, Leporati P, Carbone A, Croce L, Magri F, Chiovato L, Rotondi M. Normal human thyroid cells, BCPAP, and TPC-1 thyroid tumor cell lines display different profile in both basal and TNF- $\alpha$-induced CXCL8 secretion. Endocrine. 2016; 54:123-128. https://doi. org/10.1007/s12020-015-0764-x. [PubMed]

106. Awwad O, Coperchini F, Pignatti P, Denegri M, Massara S, Croce L, Di Buduo CA, Abbonante V, Balduini A, Chiovato L, Rotondi M. The AMPK-activator AICAR in thyroid cancer: effects on CXCL8 secretion and on CXCL8-induced neoplastic cell migration. J Endocrinol Invest. 2018; 41:1275-82. https:// doi.org/10.1007/s40618-018-0862-8. [ubMed]

107. Rotondi M, Coperchini F, Pignatti P, Magri F, Chiovato L. Metformin reverts the secretion of CXCL8 induced by TNF- $\alpha$ in primary cultures of human thyroid cells: an additional indirect anti-tumor effect of the drug. J Clin Endocrinol Metab. 2015; 100:E427-432. https://doi. org/10.1210/jc.2014-3045. [PubMed]

108. Rotondi M, Coperchini F, Awwad O, Pignatti P, Di Buduo CA, Abbonante V, Magri F, Balduini A, Chiovato L. Effect of Interferon- $\gamma$ on the Basal and the TNF $\alpha-S t i m u l a t e d$ Secretion of CXCL8 in Thyroid Cancer Cell Lines Bearing Either the RET/PTC Rearrangement Or the BRAF V600e Mutation. Mediators Inflamm. 2016; 2016:8512417. https:// doi.org/10.1155/2016/8512417. [PubMed]

109. Coperchini F, Croce L, Denegri M, Awwad O, Ngnitejeu ST, Magri F, Chiovato L, Rotondi M. The anti-cancer effects of phenformin in thyroid cancer cell lines and in normal thyrocytes. Oncotarget. 2019 Sep 24. https://doi. org/10.18632/oncotarget.27266. [Epub ahead of print].

110. Coperchini F, Croce L, Denegri M, Awwad O, Ngnitejeu ST, Muzza M, Capelli V, Latrofa F, Persani L, Chiovato L, Rotondi M. The BRAF-inhibitor PLX4720 inhibits CXCL8 secretion in BRAFV600E mutated and normal thyroid cells: a further anti-cancer effect of BRAF-inhibitors. Sci Rep. 2019; 9:4390. https://doi.org/10.1038/s41598-019-40818-w. [PubMed] 